\title{
Working
}

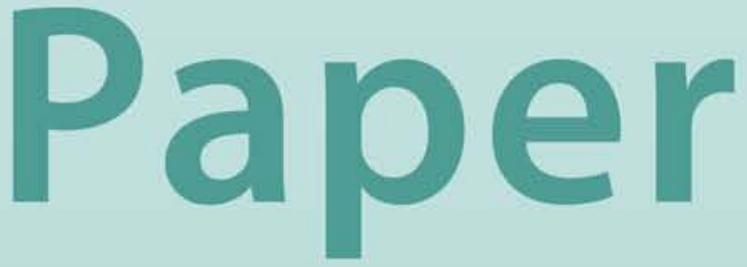




\section{Foreign Exchange Intervention in Developing and Transition Economies: \\ Results of a Survey}

Jorge Iván Canales-Kriljenko 


\title{
IMF Working Paper
}

\section{Monetary and Financial Systems Department \\ Foreign Exchange Intervention in Developing and Transition Economies: Results of a Survey}

Prepared by Jorge Iván Canales-Kriljenko ${ }^{1}$

Authorized for distribution by Shogo Ishii

May 2003

\begin{abstract}
The views expressed in this Working Paper are those of the author(s) and do not necessarily represent those of the IMF or IMF policy. Working Papers describe research in progress by the author(s) and are published to elicit comments and to further debate.
\end{abstract}

Based on evidence obtained from the IMF's 2001 Survey on Foreign Exchange Market Organization, the author argues that, for several reasons, some central banks in developing and transition economies may be able to conduct foreign exchange intervention more effectively than the central banks of developed countries issuing the major international currencies. First, these central banks do not always fully sterilize their foreign exchange interventions. In addition, they issue regulations and conduct their foreign exchange operations in a way that increases the central bank's information advantage and the size of their foreign exchange intervention relative to foreign exchange market turnover. Some of the central banks also use moral suasion to support their foreign exchange interventions.

JEL Classification Numbers: E58, F31, G28

Keywords: Foreign exchange intervention, foreign exchange market microstructure, foreign exchange net open positions, foreign exchange regulation

Author's E-Mail Address: jcanaleskriljenko@imf.org

${ }^{1}$ The author appreciates the very useful comments and suggestions received from Hervé Ferhani, Shyamala Gopinath, Roberto Guimarães, Shogo Ishii, Cem Karacadag, John Leimone, Gabriel Sensenbrenner, Susana Sosa, and Mark Zelmer. Natalie Baumer provided valued editorial assistance and Nadia Malikyar and Joanna Meza-Cuadra efficiently and diligently assisted in managing the survey responses. 


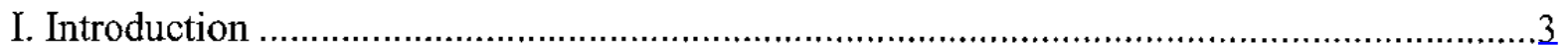

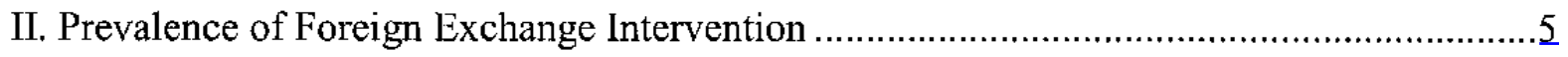

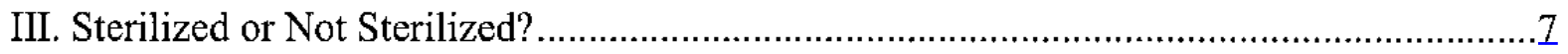

IV. Relative Size of Foreign Exchange Intervention ....................................................

A. Central Banks as Large Customers in the Foreign Exchange Market ...................10

B. Regulations that Increase the Relative Size of Foreign Exchange Intervention ......11

C. Central Bank Foreign Exchange Operating Practices That Increase the Relative Size of Foreign Exchange Intervention .....................................15

V. Information Advantage ......................................................................................

A. What Information Advantage Do Central Banks Have?....................................17

B. Information Advantage and the Transparency of Foreign

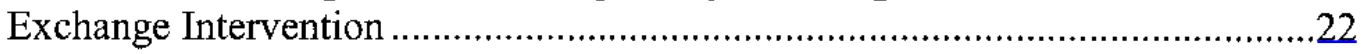

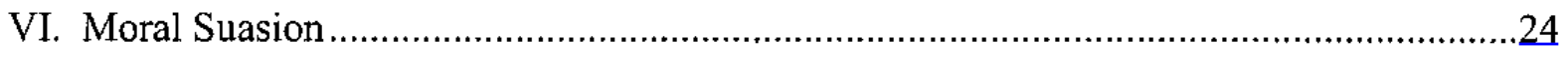

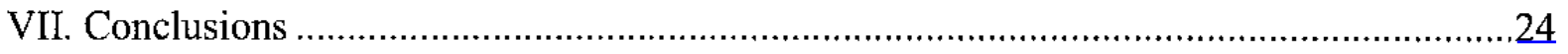

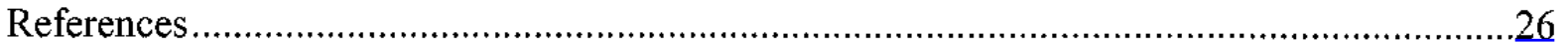

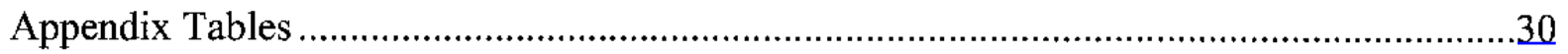




\section{INTRODUCTION}

The literature on foreign exchange intervention has focused on the experience of central banks in developed countries, especially those issuing the major international currencies. ${ }^{2,3}$ Its results suggest that sterilized foreign exchange intervention conducted by these central banks over the last 20 years may well have had an effect on the exchange rate over the short run, but not over the long run. Some authors have argued that the short-run effects have been weak and difficult to identify. ${ }^{4}$ Other authors, however, have presented a slightly more positive view about foreign exchange intervention, especially when it was conducted simultaneously by several central banks in a concerted fashion. ${ }^{5}$ These documented experiences with foreign exchange intervention have taken place in an environment of floating exchange rates, full capital mobility, and large international use of the currencies involved.

This paper explores how foreign exchange intervention can be more effective in developing and transition economies, which follow a wide array of exchange rate regimes and have in place many controls on capital mobility, currency substitution, dollarization, and the international use of their currencies. Special attention is given to the microstructure of the foreign exchange market in which the foreign exchange intervention takes place, in particular, to the aspects that can be influenced by foreign exchange regulations, monetary regulations, and central bank foreign exchange operating practices.

\footnotetext{
${ }^{2}$ Following country practices and most papers in the literature and country practices, foreign exchange intervention is defined in this paper as foreign exchange operations (buying and selling foreign exchange) undertaken by country authorities with the objective of affecting the behavior of exchange rates. Moreover, "central bank" foreign exchange intervention in this paper refers to any official foreign exchange intervention because the central bank is either the exchange rate authority or conducts foreign exchange intervention on behalf of the exchange rate authority.

${ }^{3}$ The experiences of central banks in other developed economies including Australia, Canada, Sweden, Switzerland, and the United Kingdom have also been documented in the literature with similar results to those obtained in the three major economies-many of the key characteristics of intervention, like the degree of sterilization, are the same.

${ }^{4}$ See Almekinders (1995), Baillie and others (1999), Eijffinger (1998), Frenkel and others (2001), Galati and Melick (1999), Humpage (1996 and 1999), and Rosenberg (1996).

${ }^{5}$ For example, Catte and others (1994), Dominguez (1998), Dominguez and Frankel (1993), Fatum (2000), Fatum and Hutchinson (1999), and Ito (2002).
} 
Foreign exchange intervention practices in developing and transition economies are characterized with information from the IMF's 2001 Survey on Foreign Exchange Market Organization, which targeted those developing and transition economies that are members of the IMF. ${ }^{6}$ Ninety members responded to the survey, accounting for 85 percent of the exports, 91 percent of the imports, and 85 percent of the GDP of developing and transition economies in the year 2000. These countries also held about 90 percent of the developing and transition economies' international reserves. ${ }^{7}$

The survey results suggest that official foreign exchange intervention conducted by some central banks in developing and transition economies may have more of an impact on the path of the exchange rate than official foreign exchange intervention by the central banks of developed countries issuing the major international currencies, at least in the absence of a major crisis. Several reasons can be offered. First, unlike the U.S. Federal Reserve Board (the Fed), the European Central Bank (ECB), or the Bank of Japan, not all central banks in developing and transition economies routinely fully sterilize their foreign exchange interventions. Second, unlike the central banks issuing the major international currencies, some central banks in developing and transition economies conduct foreign exchange intervention in amounts that are important relative to the level of foreign exchange market turnover, the money base, and the stock of domestic bonds outstanding. Third, some central banks in developing and transition economies have a greater information advantage over the central banks issuing the major international currencies because, among other things, they can infer the aggregate foreign exchange order flow from reporting requirements. Many central banks in developing and transition economies also use foreign exchange and monetary regulations, as well as their own foreign exchange operating practices, among other things, to increase the central bank's information advantage and the size of foreign exchange intervention relative to the market. ${ }^{8}$ Finally, many central banks in developing and transition economies exert moral suasion to reinforce the effects of their foreign exchange market interventions.

The remainder of this paper is organized as follows. Section II describes the prevalence of foreign exchange intervention across different exchange rate regimes and degrees of market access. Section III discusses the survey responses on the issue of sterilization and compares them with the sterilization practices by the central banks issuing the major international currencies. Section IV presents evidence on the size of foreign exchange intervention relative to the market in developing and transition economies and discusses how foreign exchange

${ }^{6}$ The survey results presented in this paper thus expand the work of Cheung and Chin (2001) and Neely (2000).

${ }^{7}$ The overall response rate was 60 percent (Appendix Table 1).

${ }^{8}$ The main participants in the foreign exchange market are often identified in the literature as dealers, brokers, and customers. 
regulations, monetary regulations, and central bank foreign exchange operating practices could increase the relative size and effectiveness of foreign exchange intervention. Section $\mathrm{V}$ discusses the asymmetric information in favor of central banks in developing and transition economies and discusses how the information asymmetry could increase the effectiveness of foreign exchange intervention. Section VI discusses moral suasion and Section VII concludes the analysis.

\section{PREVALENCE OF Foreign EXCHANGE INTERYENTION}

Central banks issuing the major international currencies are not active participants in their foreign exchange markets. The economies in which they operate have adopted monetary policy frameworks that target short-term interest rates and exchange rate policies that limit foreign exchange intervention to calm disorderly market conditions. ${ }^{9}$ Foreign exchange intervention takes place infrequently, and although it could be of large absolute magnitude when it does take place, its size is estimated to be small relative to total foreign exchange market turnover. ${ }^{10}$ Partly because conditions in the foreign exchange market were orderly during 2001, only the Bank of Japan conducted foreign exchange intervention operations on a very small number of days in 2001. In particular, the Bank of Japan intervened on seven days following the terrorist attacks of September 11 and on three of those days, the ECB conducted foreign exchange interventions on behalf of the Bank of Japan under an existing agreement. ${ }^{11}$ However, neither the Fed nor the ECB conducted official foreign exchange intervention on its own behalf in their spot foreign exchange markets. ${ }^{12}$,

${ }^{9}$ While no widely accepted definition of disorderly market conditions exists and the interpretation of this concept is likely to vary across central banks and over time, central banks are likely to consider disorderly market conditions characterized by large intraday exchange rate fluctuations, a sharp widening of bid-offer spreads, and sharp changes in foreign exchange market turnover.

${ }^{10}$ The exception may be the foreign exchange intervention conducted by the Bank of Japan, which is the most active of the three central banks issuing the major international currencies (see discussion on the size of foreign exchange intervention below).

11 For information about the ECB's foreign exchange intervention operations, see European Central Bank (2001); for Japan, see http://www.mof.go.jp/english/elc021.htm; and for the United States, see http://www.ny.frb.org/pihome/news/forex/.

12 The ECB drew on three days from a foreign exchange swap arrangement signed with the U.S. Federal Reserve Bank of New York in the aftermath of the terrorist attacks, which alleviated liquidity demands that could have otherwise generated large pressures on the exchange rate. However, it cannot be considered foreign exchange intervention because the purpose of the operation was not to affect exchange rates but to smooth potential disruptions in the payment systems. Moreover, although a foreign exchange swap theoretically involves 
Most central banks in developing and transition economies participated in their foreign exchange markets across all exchange rate regimes and degrees of market access during 2001. Almost all of the survey respondents reported that their central banks traded foreign exchange in the spot foreign exchange market and virtually all of those who answered the corresponding question indicated conducting foreign exchange intervention (Appendix Table 2). ${ }^{13}$ Most of the foreign exchange intervention took place in spot foreign exchange markets through foreign exchange transactions arranged by telephone conversations with banks as main counterparties (Appendix Table 3). ${ }^{14}$

The prevalence of foreign exchange intervention can be seen even in the more flexible exchange rate regimes. ${ }^{15}$ For example, in a managed floating exchange rate regime, the monetary authority influences the movements of the exchange rate through interest rate changes and active foreign exchange intervention, without specifying (or precommitting to) a preannounced path for the exchange rate. In an independently floating exchange rate regime, foreign exchange intervention may be conducted to moderate the rate of change of the exchange rate and preventing undue fluctuations in the exchange rate, rather than establishing a level for it. These intervention policies are consistent with the Fund's Principles for the Guidance of Members' Exchange Rate Policies, which call for a Fund member's foreign exchange intervention "if necessary to counter disorderly conditions, which may be characterized, among other things, by disruptive short-term movements in the exchange value of its currency."16

Conversely, little foreign exchange intervention is seen in some of the less flexible exchange rate regimes. The survey results do not support the view that central banks manage all the least flexible exchange rate regimes with frequent foreign exchange intervention. This finding may be surprising because, in the typical textbook exposition of fixed exchange rate regimes, the central bank stands ready to buy or sell foreign exchange to defend a given level of the exchange rate. Killeen and others (2001) provide a possible explanation within a foreign exchange market operating without controls. In their model, the private sector, not

simultaneous spot and forward foreign exchange operations, market makers hedge their exposure by operations in the money market rather than on the foreign exchange market.

${ }^{13}$ The Survey did not obtain information about the frequency of foreign exchange intervention in developing and transition economies.

${ }^{14}$ For an analysis of these and other operational aspects of foreign exchange intervention, see Canales-Kriljenko, Guimarães, and Karacadag (2003, forthcoming).

${ }^{15}$ Exchange rate regime classification based on de facto policies is discussed in Ishii and others (2003).

${ }^{16}$ The Guidelines are electronically available at http:/www.imf.org/external/pubs/ft/sd/index.asp?decision $=5392-(77 / 63)$. 
the central bank, absorbs the innovations in the foreign exchange order flow when the fixed exchange rate regime is credible. ${ }^{17}$ When exchange rate expectations are anchored, foreign exchange intermediaries would buy foreign exchange in the presence of pressures for domestic currency depreciation and sell it in the presence of those for currency appreciation. In other words, foreign exchange intermediaries would conduct stabilizing speculation, whose profitability would depend on the size of the bid-offer spread.

\section{STERILIZED OR Not STERILIZEd?}

Foreign exchange intervention by central banks in developing and transition economies may be more effective in affecting exchange rates than foreign exchange intervention by the central banks issuing the major international currencies, among other things, because the foreign exchange intervention by the former is not always fully sterilized.

The economic literature on foreign exchange intervention recognizes that unsterilized foreign exchange intervention has an effect on the path of exchange rates (Almekinders, 1995). Changes in the money supply have a long-run effect on its price in terms of goods and other currencies, although the adjustment on the exchange rate is usually much faster than that on goods' prices and may involve overshooting. The change in the money supply used to achieve an exchange rate objective may be accomplished by either unsterilized foreign exchange intervention or changes in the central bank's net domestic assets. ${ }^{18}$

When central banks issuing the major international currencies intervene, they tend to sterilize their foreign exchange interventions to achieve their short-term operating targets of monetary policy, usually short-term interest rates (Craig and Humpage, 2001). The Fed sterilizes its foreign exchange intervention to keep the amount of bank reserves at levels that are consistent with the established monetary policy goals. ${ }^{19}$ In particular, liquidity is adjusted for consistency with the federal funds target. The ECB has sterilized its foreign exchange

${ }^{17}$ The foreign exchange order flow is transaction volume that is given a positive sign for foreign exchange transactions initiated by buyers of foreign exchange and a negative sign for those initiated by sellers of foreign exchange. Thus, aggregate foreign exchange order flow is a measure of excess demand for foreign exchange.

${ }^{18}$ Several developing and transition economies use unsterilized foreign exchange operations instead of money market operations to achieve other domestic or external objectives. In particular, in thin domestic money markets it may be more efficient to manage liquidity through unsterilized foreign exchange operations.

${ }^{19}$ See U.S. Fed Point 44 available at http://www.ny.frb.org/pihome/fedpoint/fed 44 .html. 
intervention on the few occasions that it has been in the market (Frenkel and others, 2001). ${ }^{20}$ The Bank of Japan conducts foreign exchange intervention as the agent of the Minister of Finance with funds from a special account of the Japanese Government. Thus, foreign exchange intervention does not affect the money base. Foreign exchange purchases are funded by issuing short-term yen-denominated bills and yen purchases by selling foreign exchange funds from the special account in the market (Bank of Japan, 2000 and Ito, 2002).

Unlike the Fed, the ECB, or the Bank of Japan, not all central banks in developing and transition economies routinely fully sterilize their foreign exchange interventions. In particular, about 10 percent of the survey respondents reported that foreign exchange intervention is never sterilized; about half indicated that it is sometimes sterilized; and about 20 percent said it is always sterilized. About 25 percent of survey respondents did not answer the corresponding section of the survey.

The frequency of sterilization varied slightly by exchange rate regime and market access. Countries that sometimes sterilize their foreign exchange interventions can be found in almost all types of exchange rate regimes (Appendix Table 4). The countries that never sterilize are concentrated in the less flexible exchange rate regimes as could be expected, but account for only a small share of all countries following these exchange rate regimes (Appendix Table 5). The countries that always sterilize their foreign exchange interventions are more likely to be found in the more flexible exchange rate regimes with market access, but can also be found in countries following soft peg exchange rate regimes (Appendix Table 6).

The finding that central banks in developing and transition economies do not always fully sterilize their foreign exchange interventions should not be surprising. Unlike the major central banks that follow short-term interest rate targets, these countries follow a wide array of monetary policy frameworks that allow some room for unsterilized intervention. In addition, many authors have argued that under certain conditions, the optimal degree of sterilization is not necessarily fully sterilizing one's foreign exchange intervention and depends on the nature of the shocks that hit the economy and the objectives of the authorities. ${ }^{21}$ This literature revolves around the issue of the optimal exchange rate regime. Of course, whether developing and transition economies were actually following optimal sterilization rules is an empirical issue that is beyond the scope of this paper.

\footnotetext{
${ }^{20}$ The intervention operations conducted during 2001 by the ECB, and not considered in Frenkel and others (2001), were also sterilized. In particular, the foreign exchange intervention conducted on behalf of the Bank of Japan did not affect the money base.

${ }^{21}$ See Boyer (1978), Buiter (1979), Jones (1984), and Roper and Turnovski (1980).
} 


\section{RElative Size of Foreign EXCHANGE INTERVENTION}

The size of foreign exchange intervention is in theory an important factor influencing the effectiveness of foreign exchange intervention. In particular, it must be large relative to the total turnover in the foreign exchange market, the stock of domestic money, or the stock of publicly traded domestic and foreign bonds held by the private sector to be effective under several possible channels of influence identified in the literature, namely the balance-ofpayments-flows, monetary, and portfolio-balance channels (Rosenberg, 1996). ${ }^{22}$ Moreover, the literature has suggested that in the presence of noise traders large amounts of foreign exchange intervention may need to be involved to change the trend of the exchange rate, especially if foreign exchange intervention needs to be kept secret to be effective (Hung, 1997). ${ }^{23}$

Foreign exchange intervention by the central banks issuing the major international currencies accounts for a very small fraction of annual foreign exchange market turnover. Even in the case of the Bank of Japan, foreign exchange intervention against U.S. dollars during the year 2000 accounted for less than 0.2 percent of estimated annual foreign exchange market turnover. However, the size of foreign exchange intervention on any given day may be substantial, reaching a peak of 16 percent of foreign exchange market turnover during the period. $^{24}$

Foreign exchange intervention by some central banks in developing and transition economies accounts for a much larger fraction of foreign exchange market turnover than that conducted by central banks issuing the major international currencies, especially at the interbank level of trading (Appendix Table 7). ${ }^{25}$ In six of those countries that responded to the survey, the

22 This holds in the absence of signaling effects and changes in exchange rate expectationssee below. The balance of payments, monetary, and portfolio balance channels have been extensively discussed in the literature and will not be discussed here.

${ }^{23}$ Noise traders conduct foreign exchange transactions following trends and market sentiment rather than on the basis an analysis of the fundamental determinants of exchange rates.

${ }^{24}$ For the calculation, only total turnover in the spot market between yen and U.S. dollars is taken, as documented by the 2001 BIS Triennial Central Bank Survey of Foreign Exchange and Derivatives Market Activity. About 95 percent of foreign exchange intervention by the Bank of Japan is conducted against U.S. dollars.

${ }^{25}$ Only a few Survey respondents provided information of the amounts of foreign exchange intervention and foreign exchange market turnover that permits the comparison. To maintain confidentiality, Appendix Table 7 does not identify the names of the countries that provided the information. 
size of foreign exchange intervention exceeds the volume of interbank foreign exchange market turnover (excluding trades with the central bank). In contrast, the size of intervention is below 10 percent of the volume of interbank trading in four countries. The size of foreign exchange intervention is usually significantly smaller as a fraction of bank-customer trading, reflecting the fact that interbank trading in developing and transition economies usually accounts for only a fraction of turnover in the bank-customer segment of the market. ${ }^{26}$

Several reasons could help explain the larger size of foreign exchange intervention by some central banks in developing and transition economies relative to the sizes of their foreign exchange markets. First, central banks in these economies are usually large customers in the foreign exchange market. Second, many central banks in developing and transition economies use a variety of foreign exchange, monetary, and banking regulations to, among other things, increase their relative size in the foreign exchange market. Third, central bank foreign exchange operating practices may prevent the development of an interbank foreign exchange market containing the growth of the turnover in the foreign exchange market.

\section{A. Central Banks as Large Customers in the Foreign Exchange Market}

In contrast to the Fed, the ECB, and the Bank of Japan, many central banks in developing and transition economies are important players in the foreign exchange markets, whether on their own behalf or on behalf of their governments. Central banks in developing and transition economies may buy or sell foreign exchange as customers on their own behalf for several reasons. For instance, foreign exchange can be used to meet their foreign expenditures, such as paying their own external debt, or to sell the foreign exchange received from loans to support the balance of payments, including those from multilateral lending institutions. Central banks can also enter the foreign exchange market to adjust the actual level of international reserves to the desired level, for example, to meet some reserve adequacy targets. In addition, central banks in developing and transition economies often buy and sell foreign exchange to defend the level of the exchange rate or to reduce exchange rate volatility.

Many central banks in developing and transition economies also conduct foreign exchange operations on behalf of their governments, state enterprises, and nonbudgetary government agencies. More than half of the survey respondents reported that the central bank is the exclusive foreign exchange agent of the government with the government trading foreign exchange only with the central bank (Appendix Table 8) ${ }^{27}$ State-owned enterprises and

\footnotetext{
${ }^{26}$ In contrast, interbank trading accounts for most of the foreign exchange market turnover among the major international currencies.

${ }^{27}$ In some countries, the government is not allowed to hold foreign currency deposits and must surrender its foreign exchange to the central bank. In others, the government may keep
} 
nonbudgetary government agencies in many developing and transition economies are also required to trade foreign exchange exclusively with the central bank. This occurs with stateowned enterprises in about 8 percent of the survey respondents and government agencies in 15 percent of them.

The governments and their agencies in developing and transition economies are often a very important source of foreign exchange, especially in nonemerging markets where the size of the government in the economy is relatively large. In particular, the government, state enterprises, and nonbudgetary government agencies account for a large portion of foreign exchange traded in many countries. The concentration arises naturally in many developing and transition economies where financial aid from foreign donors is the main source of foreign exchange. It also occurs in countries where state enterprises obtain the bulk of the export receipts of the country and in some open economies where foreign exchange traded domestically mainly arises from taxes and royalties paid in foreign exchange. Finally, the government often becomes a large supplier of foreign exchange in countries where the fiscal deficit is financed abroad.

Moreover, many central banks in developing and transition economies sometimes conduct foreign exchange operations with government entities to achieve exchange rate policy objectives. In particular, on several occasions governments and state-owned companies have borrowed abroad with the main purpose of affecting the evolution of the exchange rate, rather than to finance fiscal expenditures or the companies' operations. As documented by Taylor (1982), this form of secret foreign exchange intervention was also practiced in some developed countries in the late 1970 s.

\section{B. Regulations that Increase the Relative Size of Foreign Exchange Intervention}

Many central banks in developing and transition economies often use foreign exchange controls and monetary regulations not only to directly reduce pressures on the foreign exchange market, but also to increase the effectiveness of their foreign exchange intervention by raising the size of intervention relative to the foreign exchange market. ${ }^{28}$

foreign exchange deposits in or out of the central bank, but when it decides to exchange them, it has to conduct the exchange through the central bank.

${ }^{28}$ None of the measures described in this section are currently used by the central banks issuing the major international currencies. 


\section{Foreign exchange controls}

Foreign exchange controls increase the size of foreign exchange intcrvention relative to the market by either reducing the size of the foreign exchange market or by concentrating the foreign exchange supply in the hands of the central bank.

\section{Capital controls}

If comprehensive, capital controls can reduce cross-border movements of capital and the volume of foreign exchange market turnover, increasing the relative size of central bank foreign exchange intervention. ${ }^{29}$ Banning cross-bordcr investments is a way of discouraging nonresidents from using the domestic currency and residents from using foreign currencies and thus reducing the potential volume of transactions in the foreign exchange market. Comprehensive capital controls prevent the large movement of capital and large increases in foreign exchange market turnover that accompany deviations from interest rate parity not explained by differences in risk premiums. Thus, besides the effect of increasing the relative size of foreign exchange intervention, they provide some room for maneuver to conduct independent monetary and exchange rate policies.

\section{Surrender requirements to the central bank}

A surrender requirement is an obligation to sell foreign exchange proceeds within a specified timeframe, usually from exports. When directed to the central bank, surrender requirements increase the central bank's relative size of foreign exchange intervention, bargaining position, and information advantage. Comprehensive surrender requirements of this kind concentrate the foreign exchange supply in the hands of the monetary authority and turn the central bank into the main foreign exchange intermediary. In this position, the central bank can better influence the path of the exchange rate by partially controlling the supply of foreign exchange. In practice, surrender requirements exist in about 40 percent of the survey respondents, but they are seldom directed to the central bank (Appendix Table 9). ${ }^{30}$

\section{Prohibitions on interbank foreign exchange trading}

Prohibitions on interbank foreign exchange trading limit the size of the foreign exchange market, increasing the relative size of foreign exchange intervention. In a few developing and

${ }^{29}$ For review of country experiences with the use and liberalization of capital controls, see Ariyoshi and others (2000).

${ }^{30}$ Surrender requirements to the government may be motivated by a desire to allocate foreign exchange to particular uses, to make more foreign exchange available to the central bank for foreign exchange intervention in periods of pressure on the exchange rate, and to meet public foreign exchange expenditure commitments - among the most important reasons. 
transition economies, banks are allowed to conduct foreign exchange trading only on behalf of their customers. Banks can still conduct foreign exchange intermediation, buying from sources of foreign exchange and selling to end-users of foreign exchange, but cannot engage in market making activities. The prohibitions are more likely in nonemerging markets and in the less flexible exchange rate regimes (Appendix Table 10). ${ }^{31}$

\section{Regulations hindering the taking of net open foreign exchange positions}

Limits on net open foreign exchange positions reduce the size that the foreign exchange market would have in the face of pressures on the value of the domestic currency. The rapid building of net open foreign exchange positions, such as those that take place during speculative attacks, rapidly increases the size of the foreign exchange market, decreasing the relative size of the foreign exchange intervention that is feasible with available international reserves. $^{32}$

Many central banks in developing and transition economies put in place a combination of measures to hinder the taking of net open foreign exchange positions by financial institutions. ${ }^{33}$ Most developing and transition economies impose limits on the level and daily variations of net open foreign exchange position of financial institutions (Appendix

Tables 11 and 12). The net open foreign exchange positions subject to limits usually include open forward foreign exchange positions, since unhedged forward foreign exchange positions can trigger large pressures on the spot exchange rates when banks need to hedge their exposure and cannot find an adequate counterparty to take the opposite forward foreign exchange position.

About half the survey respondents have in place measures that restrict the operation of forward markets reducing the ability of nonfinancial institutions to fund speculative positions, but also to hedge exchange rate risk. In particular, about 15 percent of survey respondents explicitly prohibit banks from issuing forward contracts and about 40 percent impose certain requirements on banks for offering forward contracts, most notably the requirement that banks offer these contracts only for hedging the exchange rate risk of legally permitted underlying international transactions. Foreign exchange regulations in some countries also control the maturity of the forward contracts offered to customers. About

${ }^{31}$ The central bank thus reduces competition from the market in setting exchange rates, which increases the impact of foreign exchange intervention on the exchange rate.

${ }^{32}$ The limits also prevent banks from excessively building their net open foreign exchange positions with foreign exchange obtained from central bank foreign exchange intervention, thus allowing the foreign exchange provided to the central bank to reach the end-customer.

${ }^{33}$ Net open foreign exchange positions also play an important prudential role limiting banks' exposure to exchange rate risk (Abrams and Beato, 1998). 
45 percent of survey respondents allow banks to issue forward contracts without any controls. However, the scope for speculative net open position taking is limited by the level of development, liquidity, and depth of the market. In particular, only 9 percent of survey respondents consider their forward foreign exchange markets to be developed, liquid, and deep, while 30 percent of survey respondents consider them to be undeveloped, illiquid, and shallow (Appendix Table 13). ${ }^{34}$

\section{Monetary regulations}

Monetary regulations can increase the relative size of central bank foreign exchange intervention by reducing the residents' use of foreign currencies and nonresidents' use of the domestic currency.

To reduce the scope for currency substitution, most countries that issue their own currencies have granted a series of legal privileges to their domestic currencies (Baliño and CanalesKriljenko, 2001). Residents usually must use their domestic currency as means of payment. In particular, monetary regulations in many of the survey respondents give the domestic currency the exclusive role of means of payment (forced tender) or, at least, the advantage of legal tender so that it must be accepted in payment for financial obligations. Moreover, about half of the survey respondents explicitly prohibit their residents from making payments to other residents in foreign currencies (Appendix Table 14).

Most countries permit residents to use foreign currencies as a store of value. Practically all survey respondents allowed banks to accept foreign currency deposits, especially from exporters. ${ }^{35}$ Some developing countries explicitly prohibit other private sector residents from holding foreign currency deposits in domestic banks. Banks may also accept foreign currency deposits from the public sector, especially from state enterprises. The number of countries allowing their financial systems to offer foreign currency deposits to nonresidents was smaller. The degree of dollarization of private sector deposits was above 10 percent in about half of the survey respondents, reaching the 75-100 range in a few countries (Appendix Table 15). ${ }^{36}$

\footnotetext{
${ }^{34}$ In contrast, about 40 percent of the Survey respondents perceived their spot foreign exchange markets to be developed, liquid, and deep, while only 6 percent perceived them to be undeveloped, illiquid, and shallow.

${ }^{35}$ When the country imposes the requirement to surrender export receipts to the foreign exchange market, the exporter can often keep foreign exchange earnings in a foreign currency account for a period before she must sell the foreign exchange.

${ }^{36}$ The Survey did not capture information on the number of countries prohibiting financial contracts from being indexed to the exchange rate, which would preserve the store of value role of foreign currencies and could give rise to exchange rate pressures.
} 
In addition, many countries imposed controls on the use of their domestic currencies by nonresidents abroad. This was the case in about a third of developing and transition economies. In addition, many countries include outright prohibitions on short-term lending in domestic currency to nonresidents to avoid fueling speculation in foreign exchange markets. In particular, about 30 percent of survey respondents explicitly prohibit their banking systems to lend domestic currency to nonresidents (Appendix Table 16).

\section{Central Bank Foreign Exchange Operating Practices That Increase the Relative Size of Foreign Exchange Intervention}

Foreign exchange operating practices by central banks can increase the size of foreign exchange intervention relative to the foreign exchange market. For example, many central banks in developing and transition economies act like market makers and set extremely narrow bid-offer spreads. ${ }^{37}$ This practice reduces foreign exchange transactions, particularly at the level of interbank trading because banks cannot compete with the central bank in conducting foreign exchange intermediation. ${ }^{38}$ The low level of foreign exchange market turnover tends to increase the relative size of the central bank intervention in the foreign exchange market.

Central banks can act as market makers in most exchange rate regimes. The central bank becomes a market maker when it sets firm two-way (buying and selling) exchange rates at which other dealers can trade, usually up to a certain amount established by market practices. For example, under a fixed exchange rate regime, central banks fix a rate and stand ready to meet any supply or demand imbalance at that rate. They may also behave as market makers in several other exchange rate regimes with different degrees of flexibility. In a crawling band, for example, the central bank sets two-way quotations with a wide bid-offer spread. In addition, central banks often conduct heavy intramarginal foreign exchange intervention to try to keep the exchange rate away from the band margins. They also could do the same even in countries following independently floating exchange rate regimes as long as they limit their foreign exchange intervention to preventing undue fluctuations in the exchange rate, rather than establishing a level for it.

A fixed bid-offer spread offered by the central bank may be smaller than the one that would prevail in the market. Without central bank participation, the bid-offer spread may vary over time and depend on country specific variables and market conditions. The bid-offer spread

${ }^{37}$ In addition, some countries directly issue regulations directly limiting the size of the bidoffer spread. In practice, many central banks in developing and transition economies set a fixed bid-offer spread across a wide variety of exchange rate regimes (Appendix Table 17).

${ }^{38}$ Narrow bid-offer spreads set by the central bank appear to have prevented the development of interbank foreign exchange markets in several Fund members. 
could increase with the exchange rate volatility (which in turn depends on the rate of currency depreciation) and decrease with expected trading volumes. The bid-offer spread increases to compensate foreign exchange intermediaries for the higher exchange rate risk associated with higher exchange rate volatility, which affects the unwanted net open foreign exchange positions that arise in the process of trading. They may dccrease with expected trading volumes reflecting economies of scale and competition among market makers. In addition, bid-offer spreads and (unexpected) trading volumes may both rise in response to the arrival of information. ${ }^{39}$ The bid-offer spread could also depend on the presence of the central bank in the foreign exchange market. In particular, when the central bank does not behave as a market maker, foreign exchange intervention can either increase or decrease the bid-offer spread. ${ }^{40}$

\section{INFORMATION ADVANTAGE}

Central banks in some developing and transition economies may be more effective in affecting exchange rates through foreign exchange intervention than those in economics issuing the major international currencies because the former have a greater information advantage over the latter. ${ }^{41}$

Foreign exchange intervention can be more effective when the central bank has an information advantage if market participants change their expectations about the future path

${ }^{39}$ These predictions are based on inventory cost models. See Galati (2000), who finds evidence of the positive correlation between bid-offer spreads and volatility but fails to find evidence of the relationship between bid-offer spreads and expected or unexpected trading volumes.

${ }^{40}$ Market makers may increase the size of the bid-offer spread when they fear they could deal with a better informed market participant, like the central bank (see Naranjo and

Nimalendran, 2000). Foreign exchange intervention could decrease the bid-offer spread when it unexpectedly increases trading volumes in the foreign exchange market.

${ }^{41}$ Having more information provides an edge to the central bank only to the extent that both groups of players (the central bank and the private sector) have the same capacity to analyzc and make inferences about the exchange rate based on the information obtained. This is clearly not the case in all developing and transition economies where the private sector may have developed an ability to make better inferences about the future path of monetary and exchange rate policies based on the publicly available information. The private sector may better analyze publicly available information than the central banks in some developing and transition economies. 
of the exchange rate after intervention operations take place. ${ }^{42}$ In such a situation, foreign exchange intervention will affect exchange rates well in excess of its contribution to aggregate foreign exchange order flow. A change in the expected exchange rate path could lead market participants to modifying their net open foreign exchange position. This could lead to a change in aggregate foreign exchange order flow, multiplying the effect of the foreign exchange intervention.

\section{A. What Information Advantage Do Central Banks Have?}

Central banks in developing and transition economies-especially in those economies that are not emerging markets - may not only have a better idea of the path for the supply of domestic currency or the targeted level of the exchange rate than other market participants, but also on the supply of foreign currency. More technically, they may have a better grasp of aggregate foreign exchange order flow than the rest of market participants. The advantage relative to the central banks issuing the major international currencies, however, consists of having a better grasp on foreign exchange order flow.

\section{More information about monetary and exchange rate developments and policies}

Like the central banks issuing the major international currencies, many central banks in developing and transition economies may, in principle, know better than other foreign exchange market participants their own intentions with respect to monetary and exchange rate policies (including foreign exchange intervention), while other market participants have to infer them from publicly available information and behavior. For example, central banks in developing and transition economies may know better their target value for the exchange rate, if any, than the rest of the participants in the foreign exchange market. In addition, some central banks in developing and transition economies may have access to information affecting exchange rates before other foreign exchange market participants, either because they compile the statistics or obtain them from the official statistical agency before the data are released. $^{43}$

\footnotetext{
${ }^{42}$ Many of the theoretical studies of the effectiveness of sterilized foreign exchange intervention rely on the existence of an information advantage to the central bank. See Eijffinger and Verhagen (1997), Lyons (2001), Mussa (1981), Popper and Montgomery (2001), and Vitale (1999).

${ }^{43}$ Many central banks in developing countries monitor the day-to-day domestic currency liquidity position of the main participants in the foreign exchange market, whether through reporting requirements or through the monitoring of accounts at the central bank to meet reserve requirements. This gives information to the central bank of which market participants have the domestic currency liquidity to buy foreign exchange in large amounts. It also allows the central bank to monitor the effect of intervention on banks' domestic currency liquidity.
} 
Some central banks in developing and transitional economies, however, may not have a real information advantage with regard to the future path of monetary policy. First, many central banks in developing and transition economies already abide by the IMF's Code of Good Practices on Transparency in Monetary and Financial Policies, which implies that they already disclose vast amounts on information about their intended policies. Second, many central banks in developing and transition economies do not have real central bank independence. Although they may formulate a comprehensive monetary program, monetary policy may need to be changed with shifting political circumstances. Moreover, the private sector may have a better sense about the potential political shifts by hiring political analysts than the authorities in charge of formulating policy. The private sector may also realize that central bank operations to contain large pressures on the currency may be futile. In particular, managing money supply in the face of large pressures may not be credible, raising interest rates may not be feasible, and foreign exchange intervention may be considered a desperate measure with no chance of success, signaling a position of vulnerability rather than of strength. Finally, the marginal advantage of getting information about fundamentals in advance of the market may not always be relevant, as sometimes high-frequency movements in the exchange rate do not reflect fundamental developments.

\section{More information about foreign exchange order flow}

To infer exchange rate pressures embedded in foreign exchange market activity, the literature on the microstructure of foreign exchange markets emphasizes the importance of foreign exchange order flow. Intuitively, a positive foreign exchange order flow reflects an excess demand for foreign exchange that would tend to depreciate the domestic currency. Lyons (2001) surveys the literature that has empirically documented the positive relationship between order flow and currency depreciation and Vitale (2001) puts forward a theoretical argument in the context of foreign exchange intervention.

Some central banks in developing and transition economies make use of their ability to issue regulations to obtain an information advantage over other market participants, among other things, about foreign exchange order flow. ${ }^{44}$ They require market participants to submit information about their foreign exchange activities, sometimes in great detail. ${ }^{45}$ The information advantage arises because only a subset of the information collected is made available to the other foreign exchange market participants. The data requested varies significantly across countries, ranging from all information on each of the foreign exchange transactions made by each authorized dealers to summary statistics, sometimes weighted by

${ }^{44}$ Authorities in most advanced economies usually do not have this prerogative established by law because the information generated in the process of trading foreign exchange within the private sector is considered to be proprietary.

${ }^{45}$ The provision of such information is often a condition for being able to conduct foreign exchange intermediation, to the extent that sometimes the obligation to provide information to the central bank is embedded in the foreign exchange license. 
the size of the transactions. The collected information available to central banks in developing and transition economies often includes data for every licensed dealer on exchange rates (whose dispersion reflects the uncertainty in the foreign exchange market) and foreign exchange transaction volumes (Appendix Table 18). ${ }^{46}$

From the information on foreign exchange transactions, central banks could infer the size of foreign exchange order flow aggregated at some levels of trading. ${ }^{47}$ For example, in transactions between banks and their customers, foreign exchange market turnover usually equals aggregate foreign exchange order flow because customers are usually those initiating the foreign exchange transaction at the exchange rate quoted by dealer banks, especially in competitive foreign exchange markets in which market makers operate. However, in transactions among banks, foreign exchange market turnover usually differs from foreign exchange order flow. It is not possible to know in a transaction among banks which bank initiated the transaction by just looking at the volume of the transaction. The lack of foreign exchange order flow data at the interbank level is less important in developing and transition economies with shallow interbank markets because interbank trading accounts for a smaller fraction of the total foreign exchange order flow in the market.

Information about the net open foreign exchange positions of authorized dealers could be used to anticipate changes in order flow, as dealers with currency exposure are likely to go to the market to cover their positions, affecting order flow, when changes in the expected path of the exchange rate take place. This information also helps identify foreign exchange dealers that may be taking large net open foreign exchange positions and contributing to pressures on the exchange rate. In most developing and transitions countries, banks must report to the central bank their net open foreign exchange positions usually more than once a month, but the information obtained is usually never published. ${ }^{48}$ The most prevalent frequency of reporting is daily. Weekly reporting is more common than monthly in all regions, except in

${ }^{46}$ The central banks issuing the major international currencies do not have the luxury of frequent data on worldwide foreign exchange market turnover involving their currencies. The statistics compiled by the Bank for International Settlements provide a snapshot of the volume traded in the worldwide foreign exchange market during one month every three years. Moreover, the information is disclosed with a lag that takes about six months.

${ }^{47}$ Reporting requirements provide a good picture of foreign exchange market turnover in a country where institutions reporting to the central bank concentrate the bulk of foreign exchange market turnover. This is more likely to be the case in about half of the countries in the sample, which actually prohibit the offshore trading of their currencies (Appendix Table 19).

${ }^{48}$ The United States requests information on the net open foreign exchange positions of the internationally active international banks every quarter, information that is available at http://www.fms.treas.gov/bulletin/index.html. 
Eastern Europe. About 70 percent of the countries with net open foreign exchange position limits, however, reported that they never published this information (Appendix Table 20).

Besides the information obtained from reporting requirements, some central banks in developing and transition economies obtain privileged information about foreign exchange order flow in some centralized trading environments, for instance, when conducting foreign exchange auctions. Central banks conducted most foreign exchange auctions in 15 countries developing and transition economies that responded to the survey (Appendix Table 21). The central bank actively participated in the auctions in three countries, but it indirectly participated in many other auctions by deciding the amounts auctioned. A few central banks in developing and transition economies also have privileged access to the information generated in electronic broking systems. ${ }^{49}$ The central bank either is the main provider or has access to the information from electronic broking systems provided by the private sector, usually adapting infrastructure available for securities' trading at stock exchanges. ${ }^{50,51}$ The central bank may be able to compute foreign exchange order flow directly in countries where it observes foreign exchange transactions that take place among banks through an electronic broking system. However, this would only cover a fraction of the total foreign exchange order flow, since banks can usually trade among each other outside of those trading platforms.

The control of the payment and settlement systems in the country could also give a marginal information edge to the central bank, as many central banks in developing and transition economies are directly involved in the settlement of foreign exchange transactions. In particular, they allow the settlement of one or both legs of foreign exchange transactions at central bank accounts. In many of the countries represented by survey respondents, where financial institutions are often required to open accounts at the central bank to meet reserve

${ }^{49}$ In electronic broking systems, market participants place orders to buy or sell foreign exchange--orders which are electronically matched in a centralized scheme.

${ }^{50}$ Electronic broking systems are in place in about 40 percent of emerging market economies (Appendix Table 22).

${ }^{51}$ Granting access to information from electronic broking systems is not the norm in developed or developing and transition countries. The most widely used electronic broking systems in developing and transition economies are the Reuters 2000-2 and 3000-Spot matching systems, which do not grant access to the trading information to the central bank. The most widely used electronic broking system for trading the major international currencies is EBS. The trading protocol in this system does not allow the central bank to accurately measure the amount being traded and it is very unlikely that EBS would grant access to privileged information to the central banks issuing the major international currencies. Of the currencies of developing and transition economies, only those of Mexico and Singapore are currently traded in EBS. 
requirements, the debiting and crediting take place at central bank accounts. The foreign currency leg settlement requires that foreign currency accounts be opened at the central bank, a situation that often arises in dollarized economies in which the reserve requirements on foreign currency deposits are denominated in foreign currency (Appendix Table 23). ${ }^{52}$ However, the information advantage obtained from the control of the payment and settlement systems may be difficult to obtain in practice unless special arrangements for the settlement of foreign exchange transactions are in place to distinguish foreign exchange from other transactions.

Some other central banks in developing and transitional economies, however, may not have a real information advantage with regard to foreign exchange order flow. In economies where the banking system is highly concentrated, the few institutions controlling the bulk of foreign exchange transactions can get a very good grasp of the direction of aggregate foreign exchange order flow by observing a representative fraction of it. Being in close contact with the end customers, these institutions can arguably have a better understanding of prevailing market sentiment than the central bank, even if the central bank sees the aggregate foreign exchange order flow on a daily basis. ${ }^{53}$ The same could take place even in economies without high concentration of foreign exchange trading activity when foreign exchange dealers exchange information over the course of trading. Moreover, foreign exchange intermediaries may have access to the information about foreign exchange order flow faster than the central bank in some developing and transition economies as they get the information in real time while the central bank gets the information at the end of the day. ${ }^{54}$

52 The fact that most countries also reported that the foreign currency leg is settled at the accounts of correspondent banks abroad suggests that the central bank accounts serve as an intermediate netting scheme, but that the final payments must be done at the accounts of correspondent banks, transfering money to or from the central bank.

${ }^{53}$ Appendix Table 24 reports the number of banks, foreign exchange bureaus, voice brokers, and other market participants in many surveyed countries. It also identifies how many of those participants play the role of market makers.

${ }^{54}$ Although this is increasingly unlike as many central banks in developing and transition economies already have access to real-time information systems on exchange rates and maintain close contacts with the main market participants. 


\section{B. Information Advantage and the Transparency of Foreign Exchange Intervention}

Based on their information advantage, the central banks can choose the degree of transparency of foreign exchange intervention that makes it more effective. ${ }^{55,56}$ To produce a change in exchange rate expectations, on some occasions the central bank would need to announce its foreign exchange intervention either directly or through visible operations. For example, when the central bank believes, based on its information advantage on market fundamentals and developments, that the level the exchange rate has reached is unwarranted, the central bank could signal its intentions (or threaten) to tighten monetary policy in the future if the misalignment is not corrected. This can be done by announcing this policy and simultaneously conducting foreign exchange intervention in support of the domestic currency. An announced foreign exchange intervention could be required, besides the monetary policy announcement, to achieve the change in exchange rate expectations in countries where the authorities and institutions suffer from credibility problems (Mussa, 1981).

On other occasions, however, the central bank would benefit from keeping its foreign exchange intervention secret. ${ }^{57}$ The information advantage could allow the central bank to detect situations in which market sentiment is shifting (by observing foreign exchange order flow and bank-by-bank net open foreign exchange positions), which could allow for a change in the exchange rate trend to take place. In the presence of noise traders, secret foreign exchange intervention could produce an effect on the trading rules followed by noise traders that could lead them to change their net open foreign exchange positions and reinforce the effect of foreign exchange intervention. This effect on trading rules would be easier to achieve in when trading becomes thin in the market, but it may come at the cost of temporarily increasing exchange rate volatility (Hung, 1997). The central bank may also want to keep its foreign exchange intervention secret when it fears that the private sector would use the disclosed information against the central bank. The informational advantage to the central bank may protect it to some degree from speculative attacks and falling into speculative trading games from large traders in the market. ${ }^{58}$

${ }^{55}$ For an early discussion of the pros and cons of transparency of central bank foreign exchange operations, see Enoch, 1998.

${ }^{56}$ The Fund's Code of Good Practices on Transparency in Monetary and Financial Policies does not directly deal with issues related to the transparency of foreign exchange operations.

${ }^{57}$ It may not be so easy, however, to keep foreign exchange intervention secret, especially on a systematic basis.

${ }^{58}$ Some central banks keep secret their foreign exchange operations not intended to affect exchange rates to avoid misperceptions, while others disclose all the details of these operations for the same reason. 


\section{How transparent is foreign exchange intervention?}

The central banks issuing the major international currencies report their foreign exchange interventions with a lag, but they do not always announce their foreign exchange interventions. The Fed does not normally announce or confirm its foreign exchange intervention. The financial press often reports foreign exchange intervention activity, but formal studies disagree about their accuracy (Klein, 1993 and Osterberg and Humes, 1993). Foreign exchange intervention activity is officially reported quarterly on the web. The Fed has released daily foreign exchange intervention data with a one-year lag, for about the last 10 years. The ECB has announced some of its foreign exchange intervention operations and acknowledged that it conducted foreign exchange intervention that was not reported in the press (Fatum and Hutchinson, 2002). Foreign exchange interventions by the Bank of Japan are reported soon after they occur by news agencies and they become public information, but the Bank of Japan seldom confirms these foreign exchange interventions (Ramaswamy and Samiei, 2000). In 2002, however, the authorities released their daily foreign exchange intervention data since the early 1990 s, information that is updated quarterly. ${ }^{59}$

Central banks in developing and transition economies are divided on the issue of transparency of foreign exchange intervention. The survey results suggest that about half of the central banks in developing and transition economies that conduct foreign exchange intervention announce their presence in the foreign exchange market. The responses were very similar across emerging and nonemerging markets, but varied somewhat by exchange rate regime. In particular, countries with conventional fixed pegs and with exchange rates within crawling bands tend not to announce their foreign exchange interventions maybe because these exchange rate regimes imply that the central bank will intervene when the pegs or bands are under pressure (Appendix Table 25). In only a few countries is the announcement made before the actual foreign exchange intervention. In particular, about 16 percent of central banks in developing and transition economies conducting foreign exchange intervention announce ex ante their foreign exchange interventions in the more flexible exchange rate regimes and in some countries with conventional fixed pegs against a single currency. These announcements never take place in other exchange rate regimes (Appendix Table 26). About 25 percent of central banks that responded to the question about transparency of foreign exchange intervention indicated that they publish data on their foreign exchange interventions, sometimes with a lag (Appendix Table 27), although the figure is slightly higher for emerging markets.

${ }^{59}$ The data is available at http://www.mof.go.jp/english/e $1 \mathrm{c02} 1 . \mathrm{htm}$. 


\section{Moral Suasion}

Many central banks in developing and transition economies use moral suasion to support their foreign exchange intervention. Moral suasion is possible because the central bank usually requires a foreign exchange license for allowing institutions to conduct foreign exchange intermediation in their foreign exchange markets (Appendix Table 27). In addition, central banks in developing and transition economies are often the supervisory authority for the main authorized dealers, which are usually banks. Central banks in these countries monitor the behavior of individual market participants and threaten to withdraw the foreign exchange license, suspend an authorized dealer from conducting foreign exchange intermediation, or trigger close on-site inspections of the institutions that, for example, are perceived to increase exchange rate volatility. In addition, they use their large presence in the market to threaten not to trade with those agents that challenge the central bank's objectives in the foreign exchange market. ${ }^{60}$ Central banks could also threaten to modify foreign exchange regulations to make foreign exchange intervention more effective and affect the profitability of banks speculating against the central bank.

Foreign exchange intervention may be, or at least appear to be, more effective when the central bank exerts moral suasion. Moral suasion would provide an extra signal to market participants that the authorities are serious about a given exchange rate objective, but of course, how serious the signal is taken would depend on the funds available to the central bank for foreign exchange intervention and rate of growth of the central bank net domestic assets. In addition, excessive use of moral suasion would contribute to a lack of development of the interbank foreign exchange market and increase the relative size of the central bank in the foreign exchange market. While both moral suasion and foreign exchange intervention could contribute to a particular effect on the exchange rate, formal tests are likely to attribute the entire effect to foreign exchange intervention because it would be very difficult to control for moral suasion.

\section{Conclusions}

The evidence obtained from the IMF's 2001 Survey on Foreign Exchange Market Organization indicates that foreign exchange intervention is a widely used policy instrument in developing and transition economies. The survey provides a wealth of information about foreign exchange intervention practices, such as the degree of sterilization and transparency, as well as the environment in which these operations take place, including the main foreign exchange market structures and regulations. ${ }^{61}$

${ }^{60}$ Neely (2000) found that 23 percent of the respondents to his survey used moral suasion as an indirect method for foreign exchange intervention.

${ }^{61}$ See also Canales-Kriljenko (2003) for a deeper analysis of foreign exchange market organization in developing and transition economies. 
Central banks in some developing and transition economies may be able to conduct foreign exchange intervention more effectively than those issuing the major international currencies because they not always fully sterilize their foreign exchange intervention. In addition, central banks in many developing and transition economies issue regulations and conduct their foreign exchange operations in a way that increases the relative size of foreign exchange intervention in foreign exchange market turnover and the central bank's information advantage. In some of these countries, the regulations and foreign exchange market practices turn the central bank into one of the main foreign exchange intermediaries. Based on their information advantage, the central banks can choose the degree of transparency of foreign exchange intervention that makes it more effective. In addition, some central banks in these countries often use moral suasion to support their foreign exchange intervention. Thus, foreign exchange regulations, including pervasive capital controls, as well as moral suasion could make foreign exchange intervention more effective and are not necessarily just a substitute for intervention.

Future research should assess empirically the effectiveness of central bank foreign exchange intervention in developing and transition economies and analyze its costs and benefits when the intervention is supported by foreign exchange controls and monetary regulations. While these regulations could make foreign exchange intervention more effective, they could also force the central bank to intervene more often than otherwise. The central bank would bear all the cost of smoothing discrepancies in the arrival of orders to the foreign exchange market, because other market participants would not have the incentive to conduct stabilizing speculation. ${ }^{62}$ This could potentially increase the exchange rate volatility that would exist in the absence of foreign exchange intervention.

Moreover, even if foreign exchange intervention were effective in reducing, for example, exchange rate volatility, it would be useful to test whether the benefits of reducing exchange rate volatility compensate for the potential costs of these regulations, which may create distortions in resource allocation in the real sector and reduce the opportunities for investment, consumption smoothing, and risk sharing. Moreover, the administrative cost of enforcing the regulations could be substantial, as the authorities spend resources to enforce and update the regulations while the private sector spends resources trying to circumvent them. Efforts at circumvention may also give rise to corruption and other governance problems. Finally, exchange rate stability may be counterproductive in economies where the private sector can borrow abroad, as the private sector may underestimate the risk of loss associated with an eventual currency depreciation, which may encourage international overborrowing.

${ }^{62}$ Private sector speculation may be stabilizing or destabilizing depending on the private sector's exchange rate expectations. 


\section{REFERENCES}

Abrams, R, and P. Beato, 1998, "The Prudential Regulation and Management of Foreign Exchange Risk," IMF Working Paper 98/37 (Washington: International Monetary Fund).

Almekinders, Geert J., 1995, Foreign Exchange Intervention: Theory and Evidence, (Aldershot, U.K.).

Ariyoshi, Akira, Karl Habermeier, Bernard Laurens, Inci Otker-Robe, Jorge Iván CanalesKriljenko, and Andrei Kirilenko, 2000, Capital Controls: Country Experiences with Their Use and Liberalization, IMF Occasional Paper No. 190 (Washington: International Monetary Fund).

Baillie, Richard T., Owen F. Humpage, and William P. Osterberg, 1999, "Intervention as Information: A Survey," Federal Reserve Bank of Cleveland Working Paper No. 9918 (Cleveland, Ohio: Federal Reserve Bank).

Baliño, T., and J. Canales-Kriljenko, 2001, "Competing Monetary Roles of the U.S. Dollar, the Euro, and the Japanese Yen in Developing Countries" (unpublished; Kassel: paper prepared for the 13th Economic History Congress).

Bank of Japan, 2000, "Outline of the Bank of Japan's Foreign Exchange Intervention Operations," available via the Internet at http://www.boj.or.jp/en/about/faqkainy.htm.

Boyer, Russell S., 1978, "Optimal Foreign Exchange Intervention," The Journal of Political Economy, Vol. 86, No. 6, pp. 1045-55.

Buiter, W.,1979, "Optimal Foreign Exchange Intervention with Rational Expectations" in Trade and Payments Adjustment Under Flexible Exchange Rates, ed. by J. Martin and A. Smith (London: Macmillan).

Canales-Kriljenko, Jorge Iván, 2003, "Foreign Exchange Market Organization in Developing and Transition Economies: Results of a Survey," IMF Working Paper, forthcoming.

_- Roberto Guimarães, and Cem Karacadag, 2003, "Foreign Exchange Intervention in the Foreign Exchange Market: Elements of Best Practice," Monetary and Financial Systems Department (formarly Monetary and Exchange Affairs Department) operational paper (Washington: International Monetary Fund).

Catte, P., Galli, G., and Rebecchini, S., 1994. "Concerted Interventions and the Dollar: An Analysis of Daily Data," in The International Monetary System, ed. by P. Kenen, F. Papadia, and S. Saccomanni (Cambridge, U.K.: Cambridge University Press), pp. 201-39. 
Cheung, Y.W., and M.D. Chinn, 2001, "Currency Traders and Exchange Rate Dynamics: a Survey of the U.S. Market," Journal of International Money and Finance, Vol. 20, pp. 439-71.

Craig, Ben, and Owen Humpage, 2001, "Sterilized Intervention, Nonsterilized Intervention, and Monetary Policy," Federal Reserve Bank of Cleveland Working Paper Nos. 1-10 (July).

Dominguez, Kathryn M., 1998, "Central Bank Intervention and Exchange Rate Volatility," Journal of International Money and Finance, 17 (1) pp. 161-90, 1998.

__, and Frankel, Jeffrey A., 1993, "Foreign Exchange Intervention: An Empirical Assessment," Chapter 16 in On Exchange Rates, by J. A. Frankel, (Cambridge: MIT Press) pp. 327-45.

Eijffinger, Sylvester C. W., 1998, Foreign Exchangelintervention: Objectives and Effectiveness, Elgar Reference Collection. International Library of Critical Writings in Economics, Vol. 98 (Cheltenham, U.K. and Northampton, Mass).

Exchange Intervention, Ambiguity and Private Information," Center for Economic Research Discussion Paper No. 9730 (Tilburg University in Netherlands).

Enoch, Charles, 1998, "Transparency in Central Bank Operations in the Foreign Exchange Market," IMF Paper on Policy Analysis and Assessment /98/2 (Washington: International Monetary Fund).

European Central Bank, 2001, Annual Report, (Frankfurt: European Central Bank).

Fatum, Rasmus, 2000, "On the Effectiveness of Sterilized Foreign Exchange Intervention," ECB Working Paper No. 10. , and Michael M. Hutchison, 1999, "Is Sterilized Foreign Exchange Intervention Effective After All? An Event Study Approach," (University of California at Santa Cruz) Working Paper No. 432.

EURO: Institutional Framework, News, and Intervention," Open Economies Review, Vol. 13, No. 4, pp. 413-25(13).

Frenkel, M., C. Pierdzioch, and G. Stadtmann, 2001, "The Foreign Exchange Interventions of the ECB." Banca Nazionale Del Lavoro Quarterly Review 54:218, 249-87. 
Galati, Gabriele and William Melick, 1999, "Perceived Central Bank Intervention and Market Expectations: An Empirical Study of The Yen/Dollar Exchange Rate, 199396," BIS Working Paper Series No. 77.

,2000, "Trading Volumes, Volatility and Spreads in Foreign Exchange Markets: Evidence From Emerging Market Countries," BIS Working Paper 93.

Humpage, Owen F., 1996, "Are Successful Interventions Random Events?" Federal Reserve Bank of Cleveland Economic Commentary (March).

, 1999. "U.S. Intervention: Assessing the Probability of Success," Journal of Money Credit and Banking 31 (4):731-47.

Hung, Juann H, 1997, "Intervention Strategies and Exchange Rate Volatility: A Noise Trading Perspective," Journal of International Money and Finance, Volume 16, Issue 5,19 pp. 779-93.

Ishii, Shogo, 2003, Karl Habermeier, John Leimone, Inci Otker-Robe, and Jorge Ivan Canales-Kriljenko, 2003, Exchange Arrangements and Foreign Exchange MarketsDevelopments and Issues, IMF World Economic and Financial Survey Series (Washington: International Monetary Fund).

Ito, Takatoshi, 2002, "Is Foreign Exchange Intervention Effective?: The Japanese Experiences in the 1990s," NBER Working Paper 8914 (April). Available via the Internet at http://www.nber.org/papers/w8914.

Jones, Michael, 1984, "Optimal Foreign exchange intervention: Evidence from the Bretton Woods Era," The Review of Economics and Statistics, Vol. 66, No. 2., pp. 242-55.

Killeen, W., Lyons, R., Moore, M., 2001. Fixed Versus Flexible: Lessons from EMS Order Flow. NBER Working Paper No. 8491.

Klein, Michael W., 1993, "The Accuracy of Reports of Foreign Exchange Intervention," Journal of International Money and Finance, Vol. 12, 1993, pp. 644-53.

Lyons, R., 2001, The Microstructure Approach to Exchange Rates (Cambridge: MIT Press).

Mussa, Michael, 1981, “The Role of Official Intervention," Group of Thirty Occasional Papers Series No. 6.

Naranjo, A., and M. Nimalendran, 2000, "Government Intervention and Adverse Selection Costs in Foreign Exchange Markets," Review of Financial Studies, 13 (2), 453-77.

Neely, Christopher J., 2000, "The Practice of Central Bank Intervention: Looking Under the Hood" Federal Reserve Bank of St. Louis Review, (May/June) 83(3), pp. 1-10. 
Osterberg, William P. and Rebecca Wetmore Humes., 1993, "The Inaccuracy of Newspaper Reports of U.S. Foreign Exchange Intervention," Federal Reserve Bank of Cleveland Economic Review, Vol.29, No.4.

Popper, H., and J. Montgomery, 2001, "Information Sharing and Central Bank Intervention in the Foreign Exchange Market," Journal of International Economics, 55 (2), pp. 295-316.

Ramaswamy, Ramana and Hossein Samiei, 2000, "The Yen-Dollar Rate: Have interventions Mattered?" IMF Working Paper Series No 00/95 (Washington: International Monetary Fund).

Roper, Don E. and Stephen J. Turnovski, 1980, "Optimal Exchange Market Intervention in a Simple Stochastic Macro Model," Canadian Journal of Economics, Vol. 13, pp. 296-309.

Rosenberg, Michael Roy, 1996, Currency Forecasting: A Guide to Fundamental and Technical Models of Exchange Rate Determination (McGraw-Hill, New York).

Taylor, Dean, 1982, "Official Intervention in the Foreign Exchange Market, or Bet Against the Central Bank," Journal of Political Economy, 90 (April), pp. 256-68.

Vitale, Paolo, 1999, "Sterilized Central Bank Intervention in the Foreign Exchange Market," Journal of International Economics 49 pp. 245-67. , 2001, "Foreign Exchange Intervention, Policy Objectives, and Macroeconomic Stability," CEPR Discussion Paper No. 2886 (July). 
Table 1. Survey Response Rate, by Exchange Rate Regime and Market Access, 2001 1/

(In percent of Fund member countries in each category)

\begin{tabular}{|c|c|c|c|}
\hline \multirow[t]{2}{*}{ Exchange rate regimes $2 /$} & \multicolumn{2}{|c|}{ Developing and Transition Economies } & \multirow[t]{2}{*}{ Total } \\
\hline & Emerging Markets $3 /$ & Other & \\
\hline No country-specific currency & -- & 8 & 7 \\
\hline CAEMC 4/ & -- & 17 & 17 \\
\hline Other & -- & 17 & 13 \\
\hline Country-specific currency & 86 & 54 & 67 \\
\hline Currency board & 67 & 50 & 57 \\
\hline Conventional fixed pegs against a single currency & 88 & 63 & 70 \\
\hline Conventional fixed pegs against a composite & 100 & 71 & 80 \\
\hline $\begin{array}{l}\text { Pegs with horizontal bands within a cooperative } \\
\text { arrangement } \\
\text { Pegs with horizontal bands within a Fund supported }\end{array}$ & -- & -- & -- \\
\hline program & -- & 67 & 50 \\
\hline Crawling pegs & 100 & 67 & 75 \\
\hline Exchange rates within crawling bands & 100 & 100 & 100 \\
\hline $\begin{array}{l}\text { Managed floating, no preannounced path for } \\
\text { exchange rate } \\
\text { Independently floating }\end{array}$ & $\begin{array}{r}79 \\
100\end{array}$ & $\begin{array}{l}46 \\
42\end{array}$ & $\begin{array}{l}60 \\
63\end{array}$ \\
\hline Total & 83 & 43 & 56 \\
\hline \multicolumn{4}{|l|}{ Memo item: } \\
\hline $\begin{array}{l}\text { Total Fund Members in Developing and Transition } \\
\text { (In number of countries) }\end{array}$ & 53 & 107 & 160 \\
\hline
\end{tabular}

Note: -- stands for not applicable, zcro, or negligible amount.

Source: IMF, 2001 Survey on Foreign Exchange Market Organization.

1/ The 2001 Survey on Foreign Exchange Market Organization was sent to country authorities in all Fund member developing and transition economics on October 2001. Ninety answers were received by March 2002. Emerging market economies are in italics and underlined below.

The Survey respondents are Albania, Angola, Armenia, Azerbaijan, Bahamas, Bahrain, Bangladesh, Barbados, Belarus, Bhutan, Bolivia, Brazil, Bulgaria, Cambodia, Cape Verde, Chile, China (Mainland), Colombia, Republic of Congo, Costa Rica, Croatia, Czech Republic, Djibouti, Dominican Republic, Egypt, El Salvador, Estonia, Fiji, Ghana, Guatemala, Guyana, Honduras, Hungary, India, Indonesia, Iran, Israel, Kazakhstan, Kenya, Korea, Kuwait, Kyrgyz Republic, Lao, Latvia, Lebanon, Lesotho, Libya, Lithuania, Macedonia (FYR), Madagascar, Malaysia, Malta, Mauritius, Mexico, Moldova, Morocco, Mozambique, Namibia, Nepal, Nicaragua, Oman, Pakistan, Papua New Guinea, Paraguay, Peru, Philippines, Poland, Qatar, Romania, Samoa, Sierra Leone, Singapore, Slovak Republic, Slovenia, South Africa, Sri Lanka, Swaziland, Syria, Tanzania, Thailand, Tonga, Trinidad and Tobago, Turkey, Ukraine, United Arab Emirates, Uruguay, Vanuatu, Venezuela, Yemen, and Zambia.

2/ Follows the IMF's de facto exchange rate regime classification as published in the IMF's International Financial Statistics.

3/ Corresponds to the Fund member developing and transition countries considered as emerging markets in the Fund's internal quarterly publication named "Emerging Market Financing: A Quarterly Report on Developments and Prospects".

4/ The Central African Economic and Monetary Community (CAEMC) is itsclf a conventional fixed peg arrangement. 
Table 2. Survey Respondents Conducting Foreign Exchange Intervention, by Exchange Rate Regime and Market Access, 2001 1/

(In percent of countries answering the corresponding Survey question in each category)

\begin{tabular}{|c|c|c|c|}
\hline \multirow[t]{2}{*}{ Exchange rate regimes $2 /$} & \multicolumn{2}{|c|}{ Developing and Transition Economies } & \multirow[t]{2}{*}{ Total } \\
\hline & Emerging Markets $3 /$ & Other & \\
\hline No country-specific currency & -- & 100 & 100 \\
\hline CAEMC 4/ & -- & 100 & 100 \\
\hline Other & -- & -- & -- \\
\hline Country-specific currency & 88 & 94 & 91 \\
\hline Currency board & 50 & 100 & 67 \\
\hline Conventional fixed pegs against a single currency & 60 & 88 & 77 \\
\hline Conventional fixed pegs against a composite & 100 & 100 & 100 \\
\hline $\begin{array}{l}\text { Pegs with horizontal bands within a cooperative } \\
\text { arrangement }\end{array}$ & - & $\cdots$ & -- \\
\hline $\begin{array}{l}\text { Pegs with horizontal bands within a Fund supported } \\
\text { program }\end{array}$ & -- & 100 & 100 \\
\hline Crawling pegs & 100 & 100 & 100 \\
\hline Exchange rates within crawling bands & 80 & 100 & 83 \\
\hline $\begin{array}{l}\text { Managed floating, no preannounced path for } \\
\text { exchange ratc }\end{array}$ & 100 & 91 & 96 \\
\hline Independently floating & 91 & 100 & 94 \\
\hline Total & 88 & 94 & 91 \\
\hline \multicolumn{4}{|l|}{ Memo item: } \\
\hline Number of countries answering question & 41 & 35 & 76 \\
\hline In percent of survey respondents & 93 & 76 & 84 \\
\hline
\end{tabular}

Note: -- stands for not applicable, zero, or negligible amount.

Source: IMF, 2001 Survey on Foreign Exchange Market Organization.

1/ The 2001 Survey on Foreign Exchange Market Organization was sent to country authorities in all Fund member developing and transition economies on October 2001. Ninety answers were received by March 2002. Table 1 shows the list of respondents.

2/ Follows the IMF's de facto exchange rate regime classification as published in the IMF's International Financial Statistics.

3/ Corresponds to the Fund member developing and transition countries considered as emerging markets in the Fund's quarterly publication "Emerging Market Financing: A Quarterly Report on Developments and Prospects". 4/ The Central African Economic and Monetary Community (CAEMC) is itself a conventional fixed peg arrangement. 
Table 3. Selected Characteristics of Foreign Exchange Intervention in Developing and Transition Economies, 2001

(In percent of countries answering the corresponding Strvey question in each category)

\begin{tabular}{|c|c|c|c|c|c|c|}
\hline & \multicolumn{2}{|c|}{ Market Access } & \multicolumn{3}{|c|}{ Exchange Rate Regime 1/ } & \multirow[t]{2}{*}{ Total } \\
\hline & $\begin{array}{l}\text { Emerging } \\
\text { Markets 2/ }\end{array}$ & Other & Pegged & Intermediate & Flexible & \\
\hline \multicolumn{7}{|c|}{ Foreign exchange intervention conducted } \\
\hline in the spot market & 82 & 74 & 61 & 83 & 89 & 78 \\
\hline in the forward market & 2 & 7 & 6 & 0 & 4 & 4 \\
\hline \multicolumn{7}{|l|}{ Main counterparts } \\
\hline Banks & 100 & 91 & 94 & 100 & 96 & 96 \\
\hline Government & 84 & 85 & 82 & 100 & 82 & 84 \\
\hline Exporters and importers & 5 & 4 & 3 & 0 & 7 & 4 \\
\hline \multicolumn{7}{|l|}{ Trading Platforms } \\
\hline Telephone orders & 66 & 52 & 64 & 33 & 62 & 59 \\
\hline \multicolumn{7}{|l|}{ Online trading systems } \\
\hline Reuters 2000-1 & 36 & 28 & 33 & 25 & 33 & 32 \\
\hline Electronic broking system & 18 & 9 & 12 & 8 & 16 & 13 \\
\hline
\end{tabular}

Source: IMF, 2001 Survey on Foreign Exchange Market Organization.

1/ The exchange rate regimes group categories from the IMF's de facto exchange rate regime classification as published in the IMF's International Financial Statistics. Pegged regimes include countries without a country specific currency, currency boards, and conventional fixed peg arrangements. Intermediate regimes include pegged exchange rate within horizontal bands, crawling pegs, and exchange rates within crawling bands. Flexible regimes include managed and independently floating exchange rate regimes.

2/ Corresponds to the Fund member developing and transition countries considered as emerging markets in the Fund's quarterly publication "Emerging Market Financing: A Quarterly Report on Developments and Prospects." 
Table 4. Survey Respondents that Sometimes Sterilize Foreign Exchange Intervention, by Exchange Rate Regime and Market Access, 2001 1/

(In percent of countries answering the corresponding Survey question in each category)

\begin{tabular}{|c|c|c|c|}
\hline \multirow[t]{2}{*}{ Exchange rate regimes $2 /$} & \multicolumn{2}{|c|}{$\begin{array}{c}\text { Developing and Transition } \\
\text { Economies }\end{array}$} & \multirow[t]{2}{*}{ Total } \\
\hline & $\begin{array}{l}\text { Emerging } \\
\text { Markets 3/ }\end{array}$ & Other & \\
\hline No country-specific currency & -- & 100 & 100 \\
\hline CAEMC $4 /$ & -- & 100 & 100 \\
\hline Other & -- & -- & -- \\
\hline Country-specific currency & 61 & 67 & 63 \\
\hline Currency board & -- & -- & - \\
\hline Conventional fixed pegs against a single currency & 40 & 67 & 55 \\
\hline Conventional fixed pegs against a composite & 67 & -- & 33 \\
\hline Pegs with horizontal bands within a cooperative arrangement & -- & -- & -- \\
\hline Pegs with horizontal bands within a Fund supported program & -- & 100 & 100 \\
\hline Crawling pegs & 100 & 100 & 100 \\
\hline Exchange rates within crawling bands & 60 & 50 & 57 \\
\hline Managed floating, no preannounced path for exchange rate & 69 & 82 & 75 \\
\hline Independently floating & 60 & 67 & 63 \\
\hline Total & 61 & 68 & 64 \\
\hline \multicolumn{4}{|l|}{ Męmo item: } \\
\hline Number of countries answering question & 38 & 31 & 69 \\
\hline In percent of survey respondents & 86 & 67 & 77 \\
\hline
\end{tabular}

Note: -- stands for not applicable, zero, or negligible amount.

Source: IMF, 2001 Survey on Forcign Exchange Market Organization.

1/ The 2001 Survey on Foreign Exchange Market Organization was sent to country authorities in all Fund member developing and transition economies on October 2001. Ninety answers were received by March 2002. Table 1 shows the list of respondents.

2/ Follows the IMF's de facto exchange rate regime classification as published in the IMF's International Financial Statistics.

3/ Corresponds to the Fund member developing and transition countries considered as emerging markets in the Fund's quarterly publication "Emerging Market Financing: A Quarterly Report on Devclopments and Prospects".

4/ The Central African Economic and Monetary Community (CAEMC) is itself a conventional fixed peg arrangement. 


\section{Table 5. Survey Respondents that Never Sterilize Foreign Exchange Intervention,} by Exchange Rate Regime and Market Access, 2001 1/

(In percent of countries answering the corresponding Survey question in each category)

\begin{tabular}{|c|c|c|c|}
\hline \multirow[t]{2}{*}{ Exchange rate regimes $2 /$} & \multicolumn{2}{|c|}{$\begin{array}{c}\text { Developing and Transition } \\
\text { Economies }\end{array}$} & \multirow[t]{2}{*}{ Total } \\
\hline & Emerging Markets $3 /$ & Other & \\
\hline No country-specific currency & -- & - & -- \\
\hline CAEMC 4/ & - & -- & -- \\
\hline Other & -- & -- & -- \\
\hline Country-specific currency & 8 & 17 & 12 \\
\hline Currency board & 100 & -- & 100 \\
\hline Conventional fixed pegs against a single currency & 20 & 17 & 18 \\
\hline Conventional fixed pegs against a composite & 33 & 67 & 50 \\
\hline Pegs with horizontal bands within a cooperative arrangement & - & -- & -- \\
\hline Pegs with horizontal bands within a Fund supported program & -- & -- & -. \\
\hline Crawling pegs & -- & - & -- \\
\hline Exchange rates within crawling bands & - & -- & -- \\
\hline Managed floating, no preannounced path for exchange rate & -- & 9 & 4 \\
\hline Independently floating & -- & 17 & 6 \\
\hline Total & 8 & 16 & 12 \\
\hline \multicolumn{4}{|l|}{ Memo item: } \\
\hline Number of countries answering question & 38 & 31 & 69 \\
\hline In percent of survey respondents & 86 & 67 & 77 \\
\hline
\end{tabular}

Note: -- stands for not applicable, zero, or negligible amount.

Source: IMF, 2001 Survey on Foreign Exchange Market Organization.

1/ The 2001 Survey on Foreign Exchange Market Organization was sent to country authorities in all Fund member developing and transition economies on October 2001. Ninety answers were received by March 2002. Table 1 shows the list of respondents.

2/ Follows the IMF's de facto exchange rate regime classification as published in the IMF's International Financial Statistics.

3/ Corresponds to the Fund member developing and transition countries considered as emerging markets in the Fund's quarterly publication "Emerging Market Financing: A Quarterly Report on Developments and Prospects".

4/ The Central African Economic and Monetary Community (CAEMC) is itself a conventional fixed peg arrangement. 
Table 6. Survey Respondents that Always Sterilize Foreign Exchange Intervention, by Exchange Rate Regime and Market Access, 2001 1/

(In percent of countries answering the corresponding Survcy question in each category)

\begin{tabular}{|c|c|c|c|}
\hline \multirow[t]{2}{*}{ Exchange rate regimes $2 /$} & \multicolumn{2}{|c|}{$\begin{array}{c}\text { Developing and Transition } \\
\text { Economies }\end{array}$} & \multirow[t]{2}{*}{ Total } \\
\hline & $\begin{array}{l}\text { Emerging } \\
\text { Markets 3/ }\end{array}$ & Other & \\
\hline No country-specific currency & -- & -- & - \\
\hline CAEMC 4/ & -- & -- & -- \\
\hline Other & -- & -- & -- \\
\hline Country-specific currency & 32 & 17 & 25 \\
\hline Currency board & -- & -- & - \\
\hline Conventional fixed pegs against a single currency & 40 & 17 & 27 \\
\hline Conventional fixed pegs against a composite & -- & 33 & 17 \\
\hline Pegs with horizontal bands within a cooperative arrangement & - & -- & -- \\
\hline Pegs with horizontal bands within a Fund supported program & - & -- & -- \\
\hline Crawling pegs & - & -- & -- \\
\hline Exchange rates within crawling bands & 40 & 50 & 43 \\
\hline Managed floating, no preannounced path for exchange rate & 31 & 9 & 21 \\
\hline Independently floating & 40 & 17 & 31 \\
\hline Total & 32 & 16 & 25 \\
\hline \multicolumn{4}{|l|}{ Memo item: } \\
\hline Number of countries answering question & 38 & 31 & 69 \\
\hline In percent of survey respondents & 86 & 67 & 77 \\
\hline
\end{tabular}

Note: -- stands for not applicable, zero, or negligible amount.

Source: IMF, 2001 Survey on Foreign Exchange Market Organization.

1/ The 2001 Survey on Foreign Exchange Market Organization was sent to country authorities in all Fund member developing and transition economies on October 2001. Ninety answers were received by March 2002. Table 1 shows the list of respondents.

2/ Follows the IMF's de facto exchange rate regime classification as published in the IMF's International Financial Statistics.

3/ Corresponds to the Fund member developing and transition countries considered as emerging markets in the Fund's quarterly publication "Emerging Market Financing: A Quarterly Report on Developments and Prospects".

4/ The Central African Economic and Monetary Community (CAEMC) is itself a conventional fixed peg arrangement. 
Table 7. Magnitude of Foreign Exchange Intervention in Selected Developing and Transition Economies, 2000

(In percent of foreign exchange market turnover at different levels of trading)

\begin{tabular}{|c|c|c|c|}
\hline \multirow[b]{2}{*}{ Countries $1 /$} & \multicolumn{3}{|c|}{ Foreign exchange intervention in percent of } \\
\hline & $\begin{array}{l}\text { Interbank foreign } \\
\text { exchange market } \\
\text { turnover } 2 /\end{array}$ & $\begin{array}{c}\text { Foreign exchange } \\
\text { market turnover } \\
\text { between bank and end- } \\
\text { customers } 3 /\end{array}$ & $\begin{array}{l}\text { Foreign exchange market } \\
\text { turnover among banks } \\
\text { and between bank and } \\
\text { end-customers } 2 \text { / }\end{array}$ \\
\hline Country 1 & $5,153.4$ & 0.1 & 0.1 \\
\hline Country 2 & $1,351.7$ & 239.0 & 203.1 \\
\hline Country 3 & 161.8 & -- & -- \\
\hline Country 4 & 160.2 & 3.1 & 3.0 \\
\hline Country 5 & 138.4 & 25.7 & 21.7 \\
\hline Country 6 & 118.1 & -- & - \\
\hline Country 7 & 90.2 & 9.6 & 8.7 \\
\hline Country 8 & 59.3 & -- & -- \\
\hline Country 9 & 36.5 & 7.3 & 6.1 \\
\hline Country 10 & 32.4 & 15.9 & 10.7 \\
\hline Country 11 & 4.6 & 3.9 & 2.1 \\
\hline Country 12 & 3.0 & 19.0 & 2.6 \\
\hline Country 13 & 1.0 & -- & -- \\
\hline Country 14 & 0.0 & 0.0 & 0.0 \\
\hline Country 15 & -- & 7.4 & -- \\
\hline Country 16 & -- & 68.1 & -- \\
\hline Country 17 & -- & 5.5 & -- \\
\hline Bank of Japan 3/ & 0.2 & 0.9 & 0.1 \\
\hline
\end{tabular}

Note: -- stands for not applicable, zcro, or ncgligible amount.

Source: IMF, 2001 Survey on Foreign Exchange Market Organization; Bank of International Settlements, 2001 Triennial Central Bank Survey of Foreign Exchange and Derivatives Market Activity; and Bank of Japan.

1/ The names of the countries are omitted for confidentiality reasons.

$2 /$ The different levels of foreign exchange market turnover exclude transactions with the central bank.

3/ Foreign exchange intervention conducted in U.S. dollars in $2000 \mathrm{vs.} \mathrm{spot} \mathrm{market} \mathrm{turnover} \mathrm{of} \mathrm{the}$ yen against the US dollar on a yearly basis, as published in table E-2 of the 2001 BIS triennial Survey statistical annex. To compute the figure on a yearly basis 22 trading days are assumed each month. 
Table 8. Survey Respondents whose Central Bank is the Exclusive Foreign Exchange Agent of the Government, by Exchange Rate Regime and Market Access, 2001 1/

(In percent of member countries responding the Survey question in each category)

\begin{tabular}{|c|c|c|c|}
\hline \multirow[t]{2}{*}{ Exchange rate regimes $2 /$} & \multicolumn{2}{|c|}{$\begin{array}{c}\text { Developing and Transition } \\
\text { Economies }\end{array}$} & \multirow[t]{2}{*}{ Total } \\
\hline & $\begin{array}{l}\text { Emerging } \\
\text { Markets 3/ }\end{array}$ & Other & \\
\hline No country-specific currency & -- & 50 & 50 \\
\hline CAEMC 4/ & -. & 100 & 100 \\
\hline Other & -- & -- & - \\
\hline Country-specific currency & 52 & 63 & 58 \\
\hline Currency board & -- & -- & -- \\
\hline Conventional fixed pegs against a single currency & 43 & 75 & 63 \\
\hline Conventional fixed pegs against a composite & 67 & 40 & 50 \\
\hline Pegs with horizontal bands within a cooperative arrangement & -- & -- & -- \\
\hline Pegs with horizontal bands within a Fund supported program & -- & -- & -- \\
\hline Crawling pegs & -- & 100 & 67 \\
\hline Exchange rates within crawling bands & 60 & 100 & 71 \\
\hline Managed floating, no preannounced path for exchange rate & 60 & 55 & 58 \\
\hline Independently floating & 55 & 83 & 65 \\
\hline Total & 52 & 63 & 57 \\
\hline \multicolumn{4}{|l|}{ Memo item: } \\
\hline Number of countries answering question & 44 & 43 & 87 \\
\hline In percent of survey respondents & 100 & 93 & 97 \\
\hline
\end{tabular}

Note: -- stands for not applicable, zero, or negligible amount.

Source: IMF, 2001 Survey on Foreign Exchange Market Organization.

1/ The 2001 Survey on Foreign Exchange Market Organization was sent to country authorities in all developing and transition cconomies on October 2001. Ninety answers were received by March 2002. Table 1 shows the list of respondents.

2/ Follows the IMF's de facto exchange rate regime classification as published in the IMF's International Financial Statistics.

3/ Corresponds to the Fund member developing and transition countries considered as emerging markets in the Fund's quarterly publication "Emerging Market Financing: A Quarterly Report on Developments and Prospects".

4/ The Central African Economic and Monetary Community (CAEMC) is itself a conventional fixed peg arrangement. 
Table 9. Survey Respondents Imposing Surrender Requirements, by Exchange Rate Regime and Market Access, 2001 1/

(In percent of countries answering the corresponding Survey question in each category)

\begin{tabular}{|c|c|c|c|}
\hline \multirow[t]{2}{*}{ Exchange rate regimes $2 /$} & \multicolumn{2}{|c|}{$\begin{array}{l}\text { Developing and Transition } \\
\text { Economies }\end{array}$} & \multirow[t]{2}{*}{ Total } \\
\hline & $\begin{array}{l}\text { Emerging } \\
\text { Markets 3/ }\end{array}$ & Other & \\
\hline No country-specific currency & -- & 50 & 50 \\
\hline CAEMC 4/ & -- & 100 & 100 \\
\hline Other & -- & -- & -- \\
\hline Country-specific currency & 36 & 48 & 42 \\
\hline Currency board & -- & -- & -- \\
\hline Conventional fixed pegs against a single currency & 43 & 92 & 74 \\
\hline Conventional fixed pegs against a composite & 67 & 60 & 63 \\
\hline Pegs with horizontal bands within a cooperative arrangement & -- & -- & -- \\
\hline Pegs with horizontal bands within a Fund supported program & -- & -- & -- \\
\hline Crawling pegs & -- & -- & -- \\
\hline Exchange rates within crawling bands & -- & 100 & 29 \\
\hline Managed floating, no preannounced path for exchange rate & 40 & 18 & 31 \\
\hline Independently floating & 45 & 38 & 42 \\
\hline Total & 36 & 48 & 42 \\
\hline \multicolumn{4}{|l|}{ Mcmo item: } \\
\hline Number of countries answering question & 44 & 46 & 90 \\
\hline In percent of survey respondents & 100 & 100 & 100 \\
\hline \multicolumn{4}{|c|}{$\begin{array}{l}\text { Note: -- stands for not applicable, zero, or negligible amount. } \\
\text { Source: IMF, } 2001 \text { Annual Report on Exchange Arrangements and Exchange Restrictions (AREAER). }\end{array}$} \\
\hline \multicolumn{4}{|c|}{$\begin{array}{l}\text { 1/ The } 2001 \text { Survey on Foreign Exchange Market Organization did not include a question about surrender requirements, but } \\
\text { the information was obtained from the AREAER. }\end{array}$} \\
\hline \multicolumn{4}{|c|}{$\begin{array}{l}\text { 2/ Follows the IMF's de facto exchange rate regime classification as published in the IMF's International Financial } \\
\text { Statistics. } \\
3 \text { / Corresponds to the Fund member developing and transition countries considered as emerging markets in the Fund's } \\
\text { quarterly publication "Emerging Market Financing: A Quarterly Report on Developments and Prospects". }\end{array}$} \\
\hline \multicolumn{4}{|c|}{ 4/ The Central African Economic and Monetary Community (CAEMC) is itself a conventional fixed peg arrangement. } \\
\hline
\end{tabular}


Table 10. Survey Respondents Prohibiting Dealers to Trade on their Own Behalf, by Exchange Rate Regime and Market Access, 2001 1/

(In percent of countries answering the corresponding Survey question in each category)

\begin{tabular}{|c|c|c|c|}
\hline \multirow[t]{2}{*}{ Exchange rate regimes $2 /$} & \multicolumn{2}{|c|}{$\begin{array}{c}\text { Developing and Transition } \\
\text { Economics }\end{array}$} & \multirow[t]{2}{*}{ Total } \\
\hline & $\begin{array}{l}\text { Emerging } \\
\text { Markets 3/ }\end{array}$ & Other & \\
\hline No country-specific currency & -- & -- & -- \\
\hline CAEMC 4/ & -- &.- & -- \\
\hline Other & - & -- & -- \\
\hline Country-specific currency & 2 & 16 & 9 \\
\hline Currency board & -- & -- & - \\
\hline Conventional fixed pegs against a single currency & 14 & 33 & 26 \\
\hline Conventional fixed pegs against a composite & -. & 20 & 13 \\
\hline Pegs with horizontal bands within a cooperative arrangement & -. & -- & -. \\
\hline Pegs with horizontal bands within a Fund supported program & -- & -- & -- \\
\hline Crawling pegs & -- & -- & -- \\
\hline Exchange rates within crawling bands & -- & 50 & 14 \\
\hline Managed floating, no preannounced path for exchange rate & -. & -- & $\ldots$ \\
\hline Independently floating & -- & 13 & 5 \\
\hline Total & 2 & 15 & 9 \\
\hline \multicolumn{4}{|l|}{ Memo item: } \\
\hline Number of countries answering question & 44 & 46 & 90 \\
\hline In percent of survey respondents & 100 & 100 & 100 \\
\hline
\end{tabular}

Note: -- stands for not applicable, zero, or negligible amount.

Source: IMF, 2001 Survey on Foreign Exchange Market Organization.

1/ The 2001 Survey on Foreign Exchange Market Organization was sent to country authorities in all Fund member developing and transition economies on October 2001. Ninety answers were received by March 2002. Table 1 shows the list of respondents.

2/ Follows the IMF's de facto exchange rate regime classification as published in the IMF's International Financial Statistics.

3/ Corresponds to the Fund member developing and transition countries considered as emerging markets in the Fund's quarterly publication "Emerging Market Financing: A Quarterly Report on Developments and Prospects".

4/ The Central African Economic and Monetary Community (CAEMC) is itself a conventional fixed peg arrangement. 
Table 11. Survey Respondents Imposing Net Open Foreign Exchange Position Limits, by Exchange Rate Regime and Market Access, 2001 1/

(In percent of countries answering the corresponding Survey question in each category)

\begin{tabular}{|c|c|c|c|}
\hline \multirow[t]{2}{*}{ Exchange rate regimes $2 /$} & \multicolumn{2}{|c|}{$\begin{array}{c}\text { Developing and Transition } \\
\text { Economics }\end{array}$} & \multirow[t]{2}{*}{ Total } \\
\hline & $\begin{array}{l}\text { Emerging } \\
\text { Markets } 31\end{array}$ & Other & \\
\hline No country-specific currency & -- & 100 & 100 \\
\hline CAEMC 4/ & - & 100 & 100 \\
\hline Other & -- & 100 & 100 \\
\hline Country-specific currency & 93 & 74 & 84 \\
\hline Currency board & 100 & 50 & 75 \\
\hline Conventional fixed pegs against a single currency & 86 & 64 & 72 \\
\hline Conventional fixed pegs against a composite & 100 & 40 & 63 \\
\hline Pegs with horizontal bands within a cooperative arrangement & -- & -- & -- \\
\hline Pegs with horizontal bands within a Fund supported program & -- & 100 & 100 \\
\hline Crawling pegs & 100 & 50 & 67 \\
\hline Exchange rates within crawling bands & 100 & 100 & 100 \\
\hline Managed floating, no preannounced path for exchange rate & 87 & 91 & 88 \\
\hline Independently floating & 100 & 88 & 95 \\
\hline Total & 93 & 76 & 84 \\
\hline \multicolumn{4}{|l|}{$\underline{\text { Memo item: }}$} \\
\hline Number of countries answcring question & 44 & 45 & 89 \\
\hline In percent of survey respondents & 100 & 98 & 99 \\
\hline
\end{tabular}

Note: -- stands for not applicable, zero, or negligible amount.

Source: IMF, 2001 Survey on Foreign Exchange Market Organization.

1/ The 2001 Survey on Foreign Exchange Market Organization was sent to country authorities in all Fund member developing and transition economies on October 2001. Ninety answers were received by March 2002. Table 1 shows the list of respondents.

2/ Follows the IMF's de facto exchange rate regime classification as published in the IMF's International Financial Statistics.

3/ Corresponds to the Fund member developing and transition countries considered as emerging markets in the Fund's quarterly publication "Emerging Market Financing: A Quarterly Report on Developments and Prospects".

4/ The Central African Economic and Monetary Community (CAEMC) is itself a conventional fixed peg arrangement. 
Table 12. Daily Fluctuation Limits on Net Open Foreign Exchange Position Limits, by Exchange Rate Regime and Market Access, 2001 1/

(In percent of countrics answering the corresponding Survey question in each category)

\begin{tabular}{|c|c|c|c|}
\hline \multirow[t]{2}{*}{ Exchange rate regimes $2 /$} & \multicolumn{2}{|c|}{$\begin{array}{l}\text { Developing and Transition } \\
\text { Economies }\end{array}$} & \multirow[t]{2}{*}{ Total } \\
\hline & Emerging Markets $3 /$ & Other & \\
\hline No country-specific currency & -- & - & .- \\
\hline CAEMC 4/ &.- & -- & -- \\
\hline Other & -- & -- & -- \\
\hline Country-specific currency & 9 & 7 & 8 \\
\hline Currency board & -- & -- & -- \\
\hline Conventional fixed pegs against a single currency & 29 & 9 & 17 \\
\hline Conventional fixed pegs against a composite & - & $\ldots$ & - \\
\hline Pegs with horizontal bands within a cooperative arrangement & - & -- & -- \\
\hline Pegs with horizontal bands within a Fund supported program & -- & -- & -- \\
\hline Crawling pegs & 100 & -- & 33 \\
\hline Exchange rates within crawling bands & 20 & -- & 14 \\
\hline Managed floating, no preannounced path for exchange rate & -- & - & - \\
\hline Independently floating & -- & 25 & 11 \\
\hline Total & 9 & 7 & 8 \\
\hline \multicolumn{4}{|l|}{ Memo item: } \\
\hline Number of countries answering question & 43 & 45 & 88 \\
\hline In percent of survey respondents & 98 & 98 & 98 \\
\hline
\end{tabular}

Note: -- stands for not applicable, zero, or negligible amount.

Source: IMF, 2001 Survey on Foreign Exchange Market Organization.

1/ The 2001 Survey on Foreign Exchange Market Organization was sent to country authorities in all Fund member developing and transition economies on October 2001. Ninety answers were received by March 2002. Table 1 shows the list of respondents.

2/ Follows the IMF's de facto exchange rate regime classification as published in the IMF's International Financial Statistics.

3/ Corresponds to the Fund member developing and transition countries considered as emerging markets in the Fund's quarterly publication "Emerging Market Financing: A Quarterly Report on Developments and Prospects".

4/ The Central African Economic and Monetary Community (CAEMC) is itself a conventional fixed peg arrangement. 
Table 13. Sclected Regulations on Forward Foreign Exchange Transactions

in Developing and Transition Economies, 2001

(In percent of countries answering the Survey in each category)

\begin{tabular}{|c|c|c|c|c|c|c|}
\hline & \multicolumn{2}{|c|}{ Market Access } & \multicolumn{3}{|c|}{ Lxchange Rate Regime 1/ } & \multirow[t]{2}{*}{ Total } \\
\hline & $\begin{array}{l}\text { Emerging } \\
\text { Markets 2/ }\end{array}$ & Other & Pegged & Intcrmediatc & Flexible & \\
\hline Forward markets allowed & 89 & 63 & 70 & 58 & 84 & 76 \\
\hline Forward markets not allowed & 5 & 24 & 18 & 8 & 13 & 14 \\
\hline Not able to determine & 7 & 13 & 12 & 33 & 2 & 10 \\
\hline \multicolumn{7}{|l|}{ Types of derivative contracts } \\
\hline alDuteight forward contracts & 89 & 63 & 70 & 58 & 84 & 76 \\
\hline Nondeliverable forward contracts & 59 & 28 & 33 & 42 & 51 & 43 \\
\hline Futures & 61 & 30 & 39 & 42 & 51 & 46 \\
\hline Options & 77 & 30 & 45 & 42 & 62 & 53 \\
\hline \multicolumn{7}{|l|}{$\begin{array}{l}\text { Requirements for offering forward } \\
\text { contracts }\end{array}$} \\
\hline Quantitative limits & 11 & 20 & 18 & 17 & 13 & 16 \\
\hline $\begin{array}{l}\text { Verification of existence of legally } \\
\text { permitted underlying current or } \\
\text { capital transactions }\end{array}$ & 27 & 33 & 39 & 17 & 27 & 30 \\
\hline $\begin{array}{l}\text { Transaction made only on behalf } \\
\text { of their customers }\end{array}$ & 5 & 11 & 15 & 0 & 4 & 8 \\
\hline Freely & 66 & 24 & 30 & 33 & 58 & 44 \\
\hline Not able to determine & 2 & 0 & 0 & 0 & 2 & 1 \\
\hline \multicolumn{7}{|l|}{$\begin{array}{l}\text { Subjective Assesssment of forward } \\
\text { markets }\end{array}$} \\
\hline Developed & 34 & 7 & 21 & 8 & 22 & 20 \\
\hline Undeveloped & 48 & 52 & 42 & 67 & 51 & 50 \\
\hline Other & 11 & 2 & 6 & 0 & 9 & 7 \\
\hline Not able to determine & 7 & 39 & 30 & 25 & 18 & 23 \\
\hline Liquid & 27 & 11 & 21 & 8 & 20 & 19 \\
\hline llliquid & 43 & 35 & 39 & 42 & 38 & 39 \\
\hline Other & 18 & 0 & 6 & 8 & 11 & 9 \\
\hline Not able to determine & 11 & 54 & 33 & 42 & 31 & 33 \\
\hline Deep & 18 & 7 & 9 & 8 & 16 & 12 \\
\hline Shallow & 55 & 37 & 45 & 50 & 44 & 46 \\
\hline Other & 14 & 2 & 9 & 0 & 9 & 8 \\
\hline Not able to determine & 14 & 54 & 36 & 42 & 31 & 34 \\
\hline Devcloped, liquid, and deep & 14 & 4 & 6 & 0 & 13 & 9 \\
\hline Undeveloped, illiquid, and shallow & 32 & 30 & 27 & 42 & 31 & 31 \\
\hline
\end{tabular}

Source: IMF, 2001 Survey on Foreign Exchange Market Organization.

1/ The exchange rate regimes group categories from the LMF's de facto exchange rate regime classification as published in the IMF's International Financial Statistics. Pegged regimes include countries without a country specific currency, currency boards, and conventional fixed peg arrangements. Intermediate regimes include pegged exchange rate within horizontal bands, crawling pegs, and cxchange rates within crawling bands. Flexible regimes include managed and independently floating exchange rate regimes.

2/ Corresponds to the Fund member developing and transition countries considered as emerging markets in the Fund's quarterly publication "Emerging Market Financing: A Quarterly Report on Developments and Prospects". 
Table 14. Selected Monetary Regulations that Affect Residents

in Developing and Transition Economies, 2001

(In percent of countries responding the Survey in each category)

\begin{tabular}{|c|c|c|c|c|c|c|}
\hline & \multicolumn{2}{|c|}{ Market Access } & \multicolumn{3}{|c|}{ Exchange Rate Regime 1/ } & \multirow[t]{2}{*}{ Total } \\
\hline & $\begin{array}{l}\text { Emerging } \\
\text { Markets 2/ }\end{array}$ & Other & Pegged & Intermediate & Flexible & \\
\hline \multicolumn{7}{|l|}{ Residents prohibited from } \\
\hline $\begin{array}{l}\text { Making payments to each other in } \\
\text { foreign currencies }\end{array}$ & 48 & 57 & 58 & 33 & 53 & 52 \\
\hline Holding foreign notes and coins & 18 & 26 & 39 & 8 & 13 & 22 \\
\hline $\begin{array}{l}\text { Denominating domestic financial } \\
\text { contracts in foreign exchange }\end{array}$ & 34 & 26 & 36 & 17 & 29 & 30 \\
\hline $\begin{array}{l}\text { Holding foreign currency deposits } \\
\text { in the domestic banking system }\end{array}$ & 18 & 17 & 30 & 0 & 13 & 18 \\
\hline $\begin{array}{l}\text { Receiving foreign currency loans } \\
\text { from domestic financial } \\
\text { institutions }\end{array}$ & 25 & 26 & 36 & 8 & 22 & 26 \\
\hline $\begin{array}{l}\text { Denominating nonfinancial } \\
\text { contracts in foreign currencies }\end{array}$ & 18 & 33 & 33 & 25 & 20 & 26 \\
\hline $\begin{array}{l}\text { Holding foreign currency } \\
\text { denominated financial assets } \\
\text { abroad }\end{array}$ & 43 & 39 & 45 & 33 & 40 & 41 \\
\hline
\end{tabular}

Source: IMF, 2001 Survey on Foreign Exchange Market Organization.

1/ The exchange rate regimes group categories from the IMF's de facto exchange rate regime classification as published in the IMF's International Financial Statistics. Pegged regimes include countries without a country specific currency, currency boards, and conventional fixed peg arrangements. Intermediate regimes include pegged exchange rate within horizontal bands, crawling pegs, and exchange rates within crawling bands. Flexible regimes include managed and independently floating exchange rate regimes.

2/ Corresponds to the Fund member developing and transition countries considered as emerging markets in the Fund's quarterly publication "Emerging Market Financing: A Quarterly Report on Developments and Prospects". 
Table 15. Selected Indicators of Financial Dollarization

in Developing and Transition Economies, 2001

(In percent of countries responding the Survey in each category)

\begin{tabular}{|c|c|c|c|c|c|c|}
\hline & \multicolumn{2}{|c|}{ Market Access } & \multicolumn{3}{|c|}{ Exchange Rate Regime 1/ } & \multirow[t]{2}{*}{ Total } \\
\hline & $\begin{array}{l}\text { Emerging } \\
\text { Markets } 2 /\end{array}$ & Other & Pegged & Intermediate & Flexible & \\
\hline $\begin{array}{l}\text { Banks allowed to accept } \\
\text { foreign currency deposits } \\
\text { from residents } \\
\text { private sector }\end{array}$ & 100 & 98 & 97 & 100 & 100 & 99 \\
\hline exporters & 100 & 98 & 97 & 100 & 100 & 99 \\
\hline $\begin{array}{l}\text { nonexporters } 3 \text { / } \\
\text { public sector }\end{array}$ & 82 & 80 & 70 & 92 & 87 & 81 \\
\hline government & 34 & 30 & 33 & 58 & 24 & 32 \\
\hline state enterprises & 61 & 63 & 55 & 75 & 64 & 62 \\
\hline government agencies & 43 & 48 & 45 & 50 & 44 & 46 \\
\hline central bank & 23 & 9 & 18 & 17 & 13 & 16 \\
\hline from nonresidents 4 / & 100 & 98 & 97 & 100 & 100 & 99 \\
\hline \multicolumn{7}{|l|}{$\begin{array}{l}\text { Degree of dollarization of } \\
\text { dcposits 5/ }\end{array}$} \\
\hline Between 0 and 10 percent & 9 & 15 & 24 & 0 & 7 & 12 \\
\hline Between 10 and 20 percent & 16 & 7 & 3 & 17 & 16 & 11 \\
\hline Between 20 and 50 percent & 20 & 17 & 12 & 8 & 27 & 19 \\
\hline $\begin{array}{l}\text { Between } 50 \text { and } 75 \text { percent } \\
\text { Between } 75 \text { and } 100\end{array}$ & 5 & 13 & 3 & 25 & 9 & 9 \\
\hline percent & 2 & 9 & 0 & 17 & 7 & 6 \\
\hline Not able to determine $6 /$ & 48 & 37 & 55 & 33 & 36 & 42 \\
\hline $\begin{array}{l}\text { Banks allowed to make } \\
\text { foreign currency loans }\end{array}$ & 86 & 72 & 61 & 92 & 89 & 79 \\
\hline
\end{tabular}

Sources: IMF, 2001 Survey on Foreign Exchange Market Organization, Annual Report on Exchange Arrangements and Exchange Restrictions (AREAER), and monetary database.

1/ The exchange rate regimes group categories from the IMF's de facto exchange rate regime classification as published in the IMF's International Financial Statistics. Pegged regimes include countries without a country specific currency, currency boards, and conventional fixed peg arrangements. Intermediate regimes include pegged exchange rate within horizontal bands, crawling pegs, and exchange rates within crawling bands. Flexible regimes include managed and independently floating exchange rate regimes.

2/ Corresponds to the Fund member developing and transition countries considered as emerging markets in the Fund's quarterly publication "Emerging Market Financing: A Quarterly Report on Developments and Prospects".

3/ Considers the countries in which banks can offer foreign currency deposits and residents are allowed to hold foreign currency deposits in the banking system.

4/ Obtained from AREAER.

5/ Includes only deposits from private sector residents.

6/ The degree of dollarization is most likely below 10 percent. 
Table 16. Main Regulations on the Use on Domestic Currencies by Nonresidents in Developing and Transition Economies, 2001

(In percent of countries responding the Survey in each category)

\begin{tabular}{|c|c|c|c|c|c|c|}
\hline & \multicolumn{2}{|c|}{ Market Access } & \multicolumn{3}{|c|}{ Exchange Rate Regime 1/ } & \multirow[t]{2}{*}{ Total } \\
\hline & $\begin{array}{l}\text { Emerging } \\
\text { Markets 2/ }\end{array}$ & Other & Pegged & Intermediate & Flexible & \\
\hline \multicolumn{7}{|l|}{ Nonresidents prohibited from } \\
\hline $\begin{array}{l}\text { Making payments to each other } \\
\text { in domestic currencies. }\end{array}$ & 14 & 11 & 18 & 25 & 4 & 12 \\
\hline $\begin{array}{l}\text { Holding domestic notes and } \\
\text { coins }\end{array}$ & 11 & 9 & 15 & 8 & 7 & 10 \\
\hline $\begin{array}{l}\text { Denominating domestic } \\
\text { financial contracts in } \\
\text { domestic currency }\end{array}$ & 25 & 11 & 21 & 17 & 16 & 18 \\
\hline $\begin{array}{l}\text { Holding domestic currency } \\
\text { deposits in the domestic } \\
\text { banking system }\end{array}$ & 14 & 11 & 15 & 8 & 11 & 12 \\
\hline $\begin{array}{l}\text { Receiving domestic currency } \\
\text { loans from domestic financial } \\
\text { institutions }\end{array}$ & 36 & 20 & 30 & 8 & 31 & 28 \\
\hline $\begin{array}{l}\text { Denominating nonfinancial } \\
\text { contracts in domestic } \\
\text { currency }\end{array}$ & 11 & 11 & 15 & 33 & 2 & 11 \\
\hline $\begin{array}{l}\text { Making payments in national } \\
\text { currency abroad }\end{array}$ & 23 & 43 & 42 & 25 & 29 & 33 \\
\hline $\begin{array}{l}\text { Holding domestic currency } \\
\text { notes and coins abroad }\end{array}$ & 23 & 43 & 39 & 25 & 31 & 33 \\
\hline $\begin{array}{l}\text { Denominating international } \\
\text { financial contracts in national } \\
\text { currency }\end{array}$ & 20 & 24 & 27 & 25 & 18 & 22 \\
\hline $\begin{array}{l}\text { holding national currency } \\
\text { deposits abroad }\end{array}$ & 25 & 37 & 42 & 17 & 27 & 31 \\
\hline $\begin{array}{l}\text { receiving national currency } \\
\text { loans abroad }\end{array}$ & 27 & 35 & 39 & 25 & 27 & 31 \\
\hline $\begin{array}{l}\text { Denominating nonfinancial } \\
\text { contracts in national currency }\end{array}$ & 18 & 24 & 33 & 25 & 11 & 21 \\
\hline
\end{tabular}

Source: IMF, 2001 Survey on Foreign Exchange Market Organization.

1/ The exchange rate regimes group categories from the IMF's de facto exchange rate regime classification as published in the IMF's International Financial Statistics. Pegged regimes include countries without a country specific currency, currency boards, and conventional fixed peg arrangements. Intermediate regimes include pegged exchange rate within horizontal bands, crawling pegs, and exchange rates within crawling bands. Flexible regimes include managed and independently floating exchange rate regimes.

2/ Corresponds to the Fund member developing and transition countries considered as emerging markets in the Fund's quarterly publication "Emerging Market Financing: A Quarterly Report on Developments and Prospects". 
Table 17. Survey Respondents Setting or Mandating Fixed Bid-Offer Spreads, by Exchange Rate Regime and Market Access, 2001 1/

(In percent of countries answering the corresponding Survey question in each category)

\begin{tabular}{|c|c|c|c|}
\hline \multirow[t]{2}{*}{ Exchange rate regimes $2 /$} & \multicolumn{2}{|c|}{$\begin{array}{c}\text { Developing and Transition } \\
\text { Economies }\end{array}$} & \multirow[t]{2}{*}{ Total } \\
\hline & $\begin{array}{c}\text { Emerging } \\
\text { Markets 3/ }\end{array}$ & Other & \\
\hline No country-specific currency & -- & -- & -- \\
\hline CAEMC 4/ & -- & -- & -- \\
\hline Other & -- & -- & -- \\
\hline Country-specific currency & 30 & 48 & 39 \\
\hline Currency board & 100 & -- & 50 \\
\hline Conventional fixed pegs against a single currency & 80 & 58 & 65 \\
\hline Conventional fixed pegs against a composite & 67 & 100 & 86 \\
\hline Pegs with horizontal bands within a cooperative arrangement & -- & -- & -- \\
\hline Pegs with horizontal bands within a Fund supported program & -- & 100 & 100 \\
\hline Crawling pegs & -- & 100 & 67 \\
\hline Exchange rates within crawling bands & 40 & -- & 29 \\
\hline Managed floating, no preannounced path for exchange rate & 8 & 27 & 17 \\
\hline Independently floating & -- & 33 & 14 \\
\hline Total & 30 & 45 & 38 \\
\hline \multicolumn{4}{|l|}{ Memo item: } \\
\hline Number of countries answering question & 37 & 42 & 79 \\
\hline In percent of survey respondents & 84 & 91 & 88 \\
\hline
\end{tabular}

Note: -- stands for not applicable, zero, or negligible amount.

Source: IMF, 2001 Survey on Forcign Exchange Market Organization.

1/ The 2001 Survey on Foreign Exchange Market Organization was sent to country authorities in all Fund member developing and transition cconomies on October 2001. Ninety answers were received by March 2002. Table 1 shows the list of respondents.

2/ Follows the IMF's de facto exchange rate regime classification as published in the IMF's International Financial Statistics.

3/ Corresponds to the Fund member developing and transition countries considered as cmerging markets in the Fund's quartcrly publication "Emerging Market Financing: A Quarterly Report on Developments and Prospects".

4/ The Central African Economic and Monetary Community (CAEMC) is itself a conventional fixed peg arrangement. 
Table 18. Reporting Requirements on Foreign Exchange Transactions

in Developing and Transition Economies, 2001

(In percent of countries responding the Survey in each category)

\begin{tabular}{|c|c|c|c|c|c|c|}
\hline & \multicolumn{2}{|c|}{ Market Access } & \multicolumn{3}{|c|}{ Exchange Rate Regime 1/ } & \multirow[t]{2}{*}{ Total } \\
\hline & $\begin{array}{l}\text { Emerging } \\
\text { Markets 2/ }\end{array}$ & Other & Pegged & Intermediate & Flexible & \\
\hline Exchange rate data & 41 & 52 & 36 & 50 & 53 & 47 \\
\hline \multicolumn{7}{|l|}{ Weighted average on } \\
\hline $\begin{array}{l}\text { all bank foreign exchange sales and } \\
\text { purchases }\end{array}$ & 27 & 50 & 27 & 50 & 44 & 39 \\
\hline all bank foreign exchange sales & 18 & 28 & 12 & 17 & 33 & 23 \\
\hline all bank foreign exchange purchases & 16 & 26 & 12 & 17 & 29 & 21 \\
\hline $\begin{array}{l}\text { all foreign exchange sales and } \\
\text { purchases among banks }\end{array}$ & 25 & 33 & 15 & 33 & 38 & 29 \\
\hline $\begin{array}{l}\text { all foreign exchange sales to nonbank } \\
\text { customers }\end{array}$ & 23 & 28 & 6 & 33 & 38 & 26 \\
\hline $\begin{array}{l}\text { all foreign exchange purchases from } \\
\text { nonbank customers }\end{array}$ & 20 & 28 & 6 & 42 & 33 & 24 \\
\hline $\begin{array}{l}\text { all forward foreign cxchange sales } \\
\text { and purchases among banks }\end{array}$ & 18 & 13 & 3 & 17 & 24 & 16 \\
\hline Volume data & 89 & 80 & 73 & 92 & 91 & 84 \\
\hline $\begin{array}{l}\text { all bank foreign exchange sales and } \\
\text { purchases }\end{array}$ & 80 & 80 & 67 & 92 & 87 & 80 \\
\hline all bank foreign exchange sales & 48 & 48 & 36 & 42 & 58 & 48 \\
\hline all bank foreign exchange purchases & 48 & 48 & 36 & 42 & 58 & 48 \\
\hline $\begin{array}{l}\text { all foreign exchange sales and } \\
\text { purchases among banks }\end{array}$ & 73 & 48 & 42 & 75 & 69 & 60 \\
\hline $\begin{array}{l}\text { all foreign exchange sales to nonbank } \\
\text { customers }\end{array}$ & 9 & 11 & 9 & 8 & 11 & 10 \\
\hline $\begin{array}{l}\text { all foreign exchange purchases from } \\
\text { nonblank customcrs }\end{array}$ & 66 & 57 & 45 & 92 & 64 & 61 \\
\hline
\end{tabular}

Source: IMF, 2001 Survey on Foreign Exchange Market Organization.

1/ The exchange rate regimes group categories from the IMF's de facto exchange rate regime classification as published in the IMF's International Financial Statistics. Pegged regimes include countries without a country specific currency, currency boards, and conventional fixed peg arrangements. Intermediate regimes include pegged exchange rate within horizontal bands, crawling pegs, and exchange rates within crawling bands. Flcxible regimes include managed and independently floating exchange rate regimes.

2/ Corresponds to the Fund member developing and transition countries considered as emerging markets in the Fund's quarterly publication "Emerging Market Financing: A Quarterly Report on Developments and Prospects." 


\section{Table 19. Survey Respondents Allowing Offshore Trading of Domestic Currency, by Exchange Rate Regime and Market Access, 2001 1/}

(In percent of countries answering the corresponding Survey question in each catcgory)

\begin{tabular}{|c|c|c|c|}
\hline \multirow[t]{2}{*}{ Exchange rate regimes $2 /$} & \multicolumn{2}{|c|}{$\begin{array}{l}\text { Devcloping and Transition } \\
\text { Economies }\end{array}$} & \multirow[t]{2}{*}{ Total } \\
\hline & $\begin{array}{l}\text { Emerging } \\
\text { Markets 3/ }\end{array}$ & Other & \\
\hline No country-specific currency & -- & -- & -- \\
\hline CAEMC 4/ & -- & -- & -- \\
\hline Other & - & -- & -- \\
\hline Country-specific currency & 70 & 32 & 51 \\
\hline Currency board & 100 & 50 & 75 \\
\hline Conventional fixed pegs against a single currency & 71 & 8 & 32 \\
\hline Conventional fixed pegs against a composite & 67 & 60 & 63 \\
\hline Pegs with horizontal bands within a cooperative arrangement & -- & -- & - \\
\hline Pegs with horizontal bands within a Fund supported program & -- & 50 & 50 \\
\hline Crawling pegs & -- & 50 & 33 \\
\hline Exchange rates within crawling bands & 80 & -- & 57 \\
\hline Managed floating, no preannounced path for exchange rate & 53 & 55 & 54 \\
\hline Independently floating & 91 & 13 & 58 \\
\hline Total & 70 & 30 & 50 \\
\hline \multicolumn{4}{|l|}{ Memo item: } \\
\hline Number of countries answering question & 44 & 46 & 90 \\
\hline In percent of survey respondents & 100 & 100 & 100 \\
\hline
\end{tabular}

Note: - stands for not applicable, zero, or negligible amount.

Source: IMF, 2001 Survey on Foreign Exchange Market Organization.

1/ The 2001 Survey on Foreign Exchange Market Organization was sent to country authorities in all Fund member developing and transition economics on Oetober 2001. Ninety answers were received by March 2002. Table 1 shows the list of respondents.

2/ Follows the IMF's de facto exchange rate regime classification as published in the IMF's International Financial Statistics.

3/ Corresponds to the Fund member developing and transition countries considered as emerging markets in the Fund's quarterly publication "Emerging Market Financing: A Quarterly Report on Developments and Prospects".

4/ The Central African Economic and Monetary Community (CAEMC) is itself a conventional fixed peg arrangement. 
Table 20. Management of Net Open Foreign Exchange Positions

in Developing and Transition Economies, 2001

(In percent of countries responding the Survey in each category)

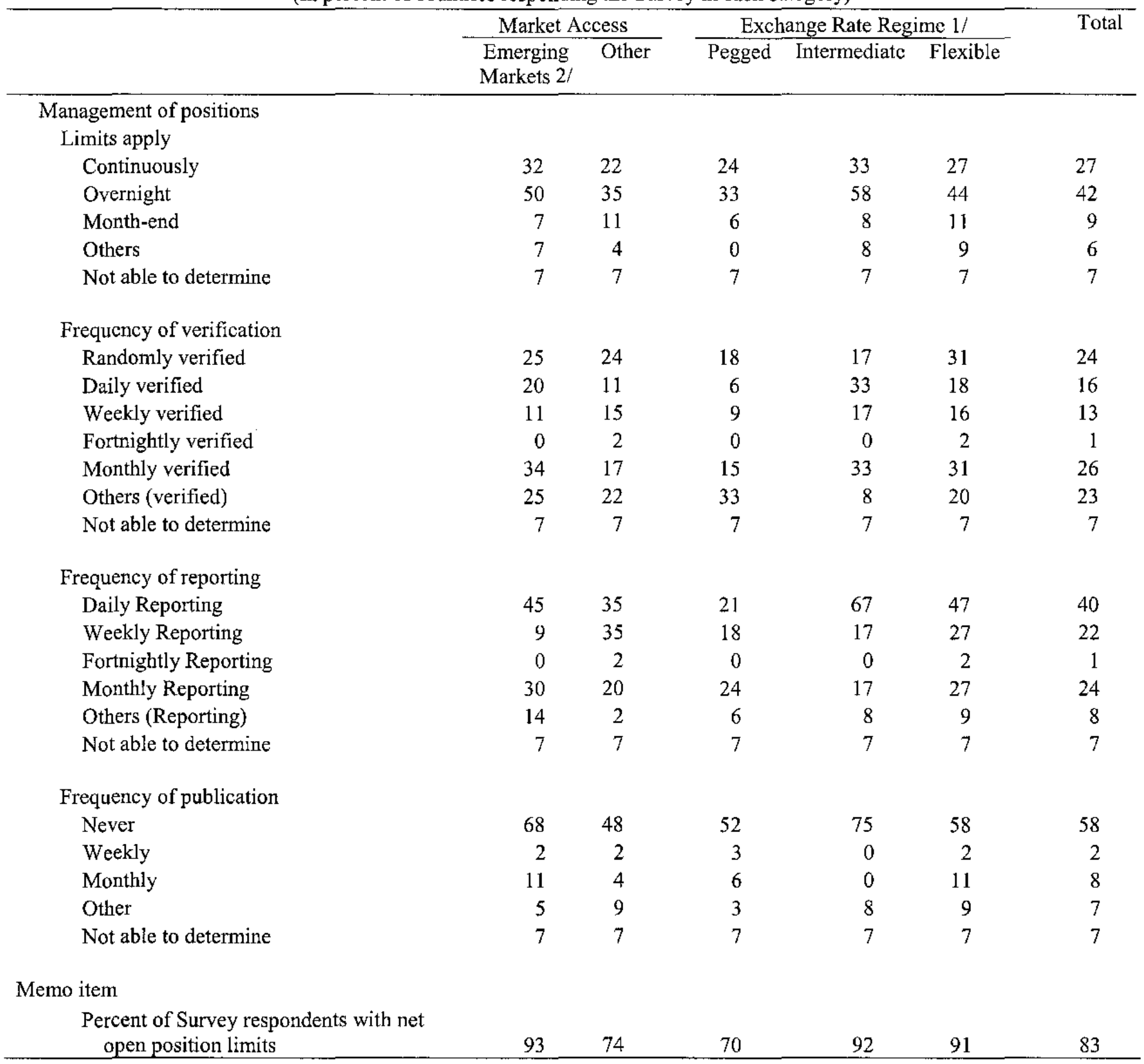

Source: IMF, 2001 Survey on Foreign Exchange Market Organization.

1/ The exchange rate regimes group categories from the IMF's de facto exchange rate regime classification as published in the IMF's International Financial Statistics. Pegged regimes include countries without a country specific currency, currency boards, and conventional fixed peg arrangements. Intermediate regimes include pegged exchange rate within horizontal bands, crawling pegs, and exchange rates within crawling bands. Flexible regimes include managed and independently floating exchange rate regimes.

2/ Corresponds to the Fund member developing and transition countries considered as emerging markets in the Fund's quarterly publication "Emerging Market Financing: A Quarterly Report on Developments and Prospects." 
Table 21. Sclected Characteristics of Foreign Exchange Auctions in Developing and Transition Economies (In number of countries)

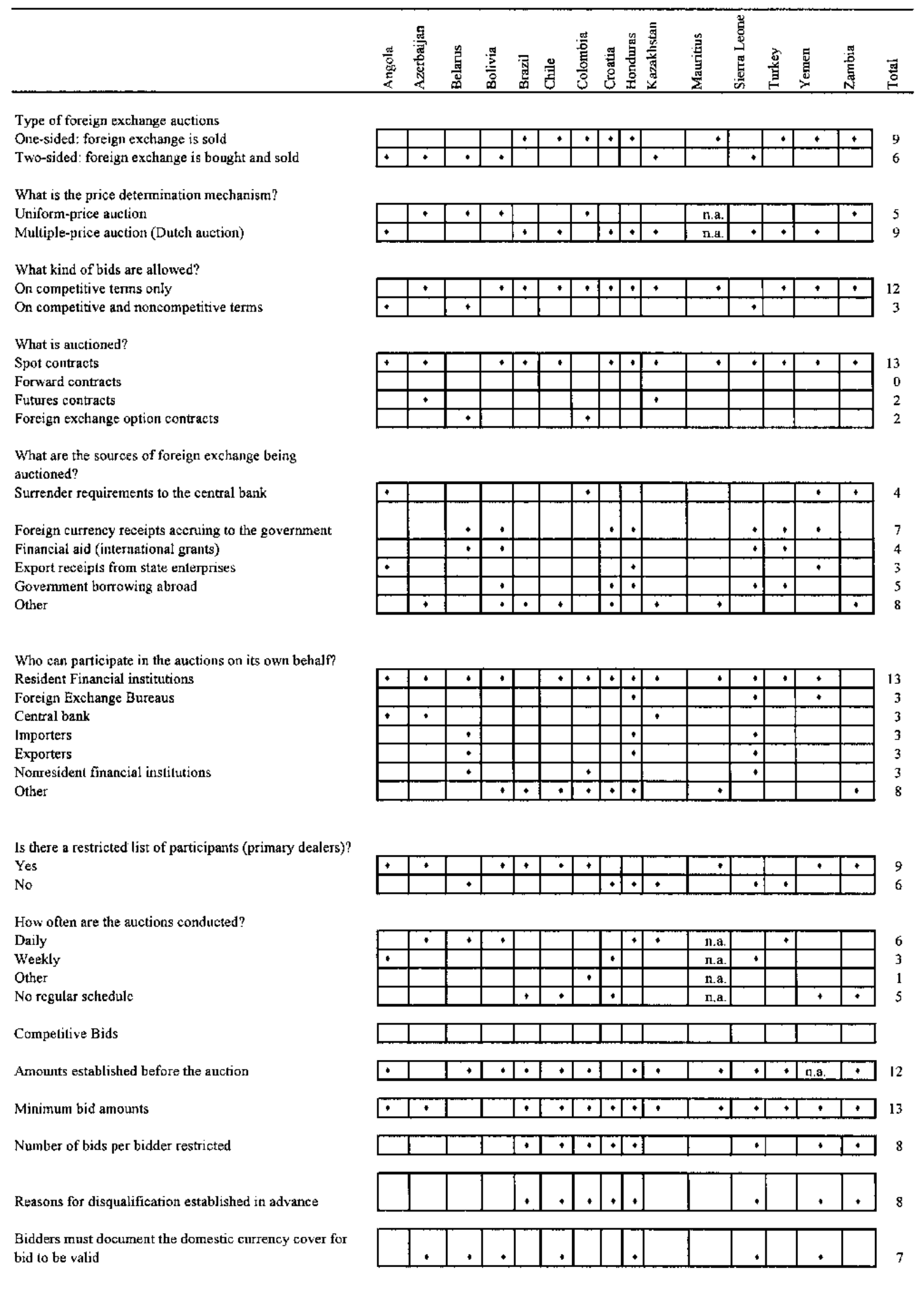

Source: IMF, 2001 Survey on Forcign Exchange Market Organization.

n.a. means not available. 
Table 22. Survey Respondents with Electronic Broking Systems, by Exchange Rate Regime and Market Access, 2001 1/

(In percent of countries answering the corresponding Survey question in each category)

\begin{tabular}{|c|c|c|c|}
\hline \multirow[t]{2}{*}{ Exchange rate regimes $2 /$} & \multicolumn{2}{|c|}{$\begin{array}{c}\text { Developing and Transition } \\
\text { Economies }\end{array}$} & \multirow[t]{2}{*}{ Total } \\
\hline & $\begin{array}{l}\text { Emerging } \\
\text { Markets 3/ }\end{array}$ & Other & \\
\hline No country-specific currency & -- & -- & -- \\
\hline CAEMC 4/ & -- & -- & -- \\
\hline Other & -- & -- & -- \\
\hline Country-specific currency & 39 & 2 & 20 \\
\hline Currency board & -- & -- & -- \\
\hline Conventional fixed pegs against a single currency & 14 & -- & 5 \\
\hline Conventional fixed pegs against a composite & -- & -- & -- \\
\hline Pegs with horizontal bands within a cooperative arrangement & -- & -- & -- \\
\hline Pegs with horizontal bands within a Fund supported program & -- & -- & -- \\
\hline Crawling pegs & 100 & -- & 33 \\
\hline Exchange rates within crawling bands & 60 & -- & 43 \\
\hline Managed floating, no preannounced path for exchange rate & 27 & 9 & 19 \\
\hline Independently floating & 73 & -- & 42 \\
\hline Total & 39 & 2 & 20 \\
\hline \multicolumn{4}{|l|}{ Memo item: } \\
\hline Number of countries answering question & 44 & 46 & 90 \\
\hline In percent of survey respondents & 100 & 100 & 100 \\
\hline
\end{tabular}

Note: -- stands for not applicable, zero, or negligible amount.

Source: IMF, 2001 Survey on Foreign Exchange Market Organization.

1/ The 2001 Survey on Foreign Exchange Market Organization was sent to country authorities in all Fund member developing and transition economies on October 2001. Ninety answers were received by March 2002 . Table 1 shows the list of respondents.

2/ Follows the IMF's de facto exchange rate regime classification as published in the IMF's International Financial Statistics.

3/ Corresponds to the Fund member developing and transition countries considered as emerging markets in the Fund's quarterly publication "Emerging Market Financing: A Quarterly Report on Developments and Prospects".

4/ The Central African Economic and Monetary Community (CAEMC) is itself a conventional fixed peg arrangement. 
Table 23. Selected Characteristics of Foreign Exchange Settlement Systems

in Developing and Transition Economies, 2001

(In percent of countries responding the Survey in each category)

\begin{tabular}{|c|c|c|c|c|c|c|}
\hline & \multicolumn{2}{|c|}{ Market Access } & \multicolumn{3}{|c|}{ Exchange Rate Regime $1 /$} & \multirow[t]{2}{*}{ Tota } \\
\hline & $\begin{array}{c}\text { Emerging } \\
\text { Markets 2/ }\end{array}$ & Other & Pegged & Intermediate & Flexible & \\
\hline \multicolumn{7}{|l|}{ Both legs are settled at accounts at } \\
\hline the central bank. & 45 & 59 & 55 & 42 & 53 & 52 \\
\hline another domestic institution & 20 & 11 & 15 & 8 & 18 & 16 \\
\hline \multicolumn{7}{|c|}{ The foreign exchange leg is settled at foreign } \\
\hline correspondent bank accounts. & 77 & 72 & 70 & 75 & 78 & 74 \\
\hline \multicolumn{7}{|l|}{ Settlement basis } \\
\hline payment versus payment & 25 & 54 & 48 & 33 & 36 & 40 \\
\hline netting & 5 & 15 & 12 & 8 & 9 & 10 \\
\hline SWIFT $3 /$ & 100 & 96 & 97 & 100 & 98 & 98 \\
\hline
\end{tabular}

Sources: IMF, 2001 Survey on Forcign Exchange Market Organization.

1 / The exchange rate regimes group categories from the LMF's de facto exchange rate regime classification as published in the IMF's International Financial Statistics. Pegged regimes include countries without a country specific currency, currency boards, and conventional fixed peg arrangements. Intermediate regimes include pegged exchange rate within horizontal bands, crawling pegs, and exchange rates within crawling bands. Flexible regimes include managed and independently floating exchange rate regimes.

2/ Corresponds to the Fund member developing and transition countries considered as emerging markets in the Fund's quarterly publication "Emerging Market Financing: A Quarterly Report on Developments and Prospects".

3/ SWIFT is the acronym for the Society for Worldwide Interbank Financial Telecommunications, which is a nonprofit cooperative of member banks based in Brussels, Belgium. By end 2001, the network was composed of over 2000 member banks in 196 countries, of which 175 were Fund members. 
Table 24. Number of Foreign Exchange Intermediaries in Developing and Transition Economies, 2001

\begin{tabular}{|c|c|c|c|c|c|c|c|c|}
\hline \multirow[b]{3}{*}{ Albania } & \multicolumn{7}{|c|}{ Foreign Exchange Dealers } & \multirow{3}{*}{$\begin{array}{c}\begin{array}{c}\text { Voice } \\
\text { brokers }\end{array} \\
\text { n.a. }\end{array}$} \\
\hline & \multirow{2}{*}{$\begin{array}{c}\text { Banks } \\
13\end{array}$} & \multirow{2}{*}{$\begin{array}{c}\text { Bureaus } \\
24\end{array}$} & \multirow{2}{*}{$\begin{array}{c}\text { Others } \\
3\end{array}$} & \multicolumn{2}{|c|}{ Total } & \multirow{2}{*}{$\begin{array}{l}\text { Of } \\
\text { which: }\end{array}$} & \multirow{2}{*}{$\begin{array}{c}\begin{array}{c}\text { Market } \\
\text { makers }\end{array} \\
10\end{array}$} & \\
\hline & & & & 40 & $1 /$ & & & \\
\hline Angola & 8 & 13 & -- & 21 & & & 1 & -- \\
\hline Armenia & 29 & 216 & 15 & 260 & $2 /$ & & n.a. & n.a. \\
\hline Azerbaijan & 52 & -- & -- & 52 & & & -- & -- \\
\hline Bahamas & 7 & -- & 2 & 9 & $1 /$ & & -- & -- \\
\hline Bahrain & 11.a. & -- & -- & 0 & & & n.a. & 4 \\
\hline Bangladesh & 605 & 518 & -- & 1123 & & & n.a. & -- \\
\hline Barbados & 8 & 1 & -- & 9 & & & 8 & - \\
\hline Belarus & 26 & -- & -- & 26 & & & -- & -- \\
\hline Bhutan & 2 & -- & $\cdots$ & 2 & & & -- & -- \\
\hline Bolivia & 12 & 44 & 39 & 95 & $1 /$ & & -- & -- \\
\hline Brazil & 119 & -- & 285 & 404 & & & 30 & 51 \\
\hline Bulgaria & 35 & 760 & -- & 795 & & & 6 & 64 \\
\hline Cambodia & 28 & 17 & -- & 45 & & & -- & -- \\
\hline Cape Verde & 4 & 3 & -- & 7 & & & -- & -- \\
\hline Chile & 25 & 5 & -- & 30 & & & n.a. & - \\
\hline Colombia & 26 & 12 & 26 & 64 & $1 / 3 /$ & & 90 & 26 \\
\hline Congo, Republic of & 13 & 24 & -- & 37 & & & 24 & -- \\
\hline Costa Rica & 21 & 2 & 11 & 34 & $1 /$ & & -- & 2 \\
\hline Croatia & 42 & -- & 13 & 55 & $1 /$ & & 5 & -- \\
\hline Czech Republic & n.a. & 13 & -- & 13 & & & 12 & 13 \\
\hline Djibouti & 3 & 4 & -- & 7 & & & -- & -- \\
\hline Dominican Republic & 14 & 100 & -- & 114 & & & n.a. & n.a. \\
\hline Egypt & 51 & 126 & - & 177 & & & -- & -- \\
\hline El Salvador & 15 & 10 & + & 25 & & & n.a. & -- \\
\hline Estonia & 7 & 190 & -- & 197 & & & 197 & n.a. \\
\hline$F \mathrm{iji}$ & 6 & 15 & -- & 21 & & & n.a. & n.a. \\
\hline Ghana & 17 & 350 & $\cdots$ & 367 & & & n.a. & -- \\
\hline Guatemala & 31 & 8 & 16 & 55 & $1 /$ & & 3 & -- \\
\hline Guyana & 7 & 28 & - & 35 & & & -- & n.a. \\
\hline Honduras & 21 & -- & 4 & 25 & l/ & & -- & 7 \\
\hline Hungary & 28 & 700 & - & 728 & & & 12.5 & -- \\
\hline India & 100 & 470 & -- & 570 & & & 10 & -- \\
\hline Iran & 10 & -- & - & 10 & & & n.a. & n.a. \\
\hline Kazakhstan & -- & 626 & -- & 626 & & & 29 & -- \\
\hline Kenya & 52 & 48 & -- & 100 & & & n.a. & - \\
\hline Korea & 70 & -- & -- & 70 & & & 9 & -- \\
\hline Kuwait & 9 & 29 & -- & 38 & & & 9 & 2 \\
\hline Kyrgyz Republic & 19 & 259 & -- & 278 & & & n.a. & n.a. \\
\hline Lao & 13 & 12 & -- & 25 & & & - & $\cdots$ \\
\hline Lebanon & 68 & 367 & 28 & 463 & $1 /$ & & I & 5 \\
\hline
\end{tabular}

Continued on next page 
Table 24. Number of Market Participants in Developing and Transition Economies, 2001 (continued)

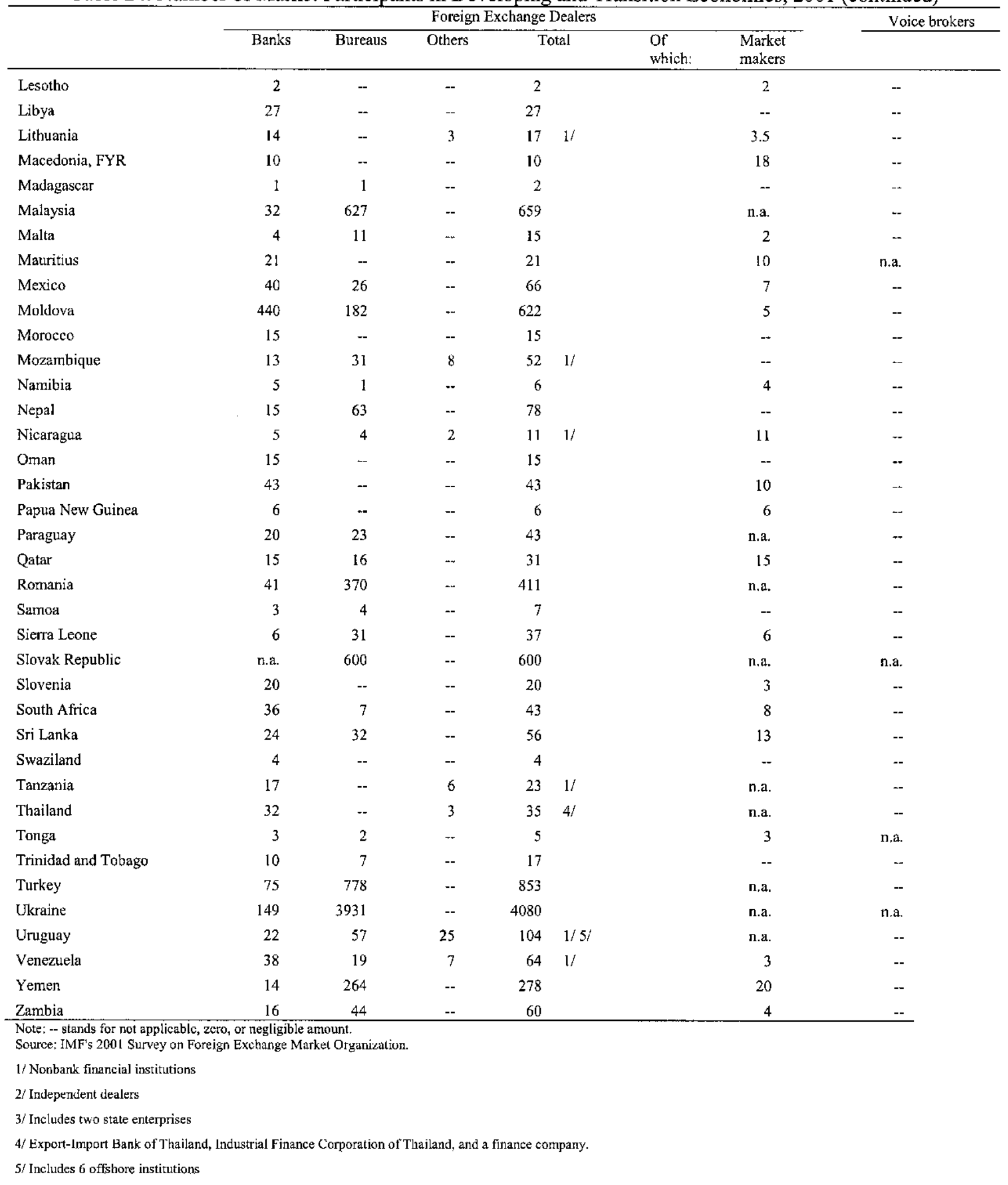


Table 25. Survey Respondents Not Announcing or Reporting Foreign Exchange Intervention, by Exchange Rate Regime and Market Access, 2001 1/

(In percent of countries answering the corresponding Survey question in each category)

\begin{tabular}{|c|c|c|c|}
\hline \multirow[t]{2}{*}{ Exchange rate regimes $2 /$} & \multicolumn{2}{|c|}{$\begin{array}{c}\text { Developing and Transition } \\
\text { Economies }\end{array}$} & \multirow[t]{2}{*}{ Total } \\
\hline & $\begin{array}{l}\text { Emerging } \\
\text { Markets 3/ }\end{array}$ & Other & \\
\hline No country-specific currency & -- & -- & -- \\
\hline CAEMC 4/ & - & -- & $\cdots$ \\
\hline Other & -- & -- & -- \\
\hline Country-specific currency & 47 & 36 & 41 \\
\hline Currency board & -- & - & -- \\
\hline Conventional fixed pegs against a single currency & 50 & 27 & 35 \\
\hline Conventional fixed pegs against a composite & 67 & 50 & 57 \\
\hline Pegs with horizontal bands within a cooperative arrangement & -- & - & -- \\
\hline Pegs with horizontal bands within a Fund supported program & $\ldots$ & -- & -. \\
\hline Crawling pegs & 100 & -- & 33 \\
\hline Exchange rates within crawling bands & 60 & 100 & 71 \\
\hline Managed floating, no preannounced path for exchange rate & 40 & 55 & 46 \\
\hline Independently floating & 45 & 25 & 37 \\
\hline Total & 47 & 34 & 40 \\
\hline \multicolumn{4}{|l|}{ Memo item: } \\
\hline Number of countries answering question & 43 & 44 & 87 \\
\hline In percent of survey respondents & 98 & 96 & 97 \\
\hline
\end{tabular}

Note: -- stands for not applicable, zero, or negligible amount.

Source: IMF, 2001 Survey on Foreign Exchange Market Organization.

1/ The 2001 Survey on Foreign Exchange Market Organization was sent to country authorities in all Fund member developing and transition economies on October 2001. Ninety answers were received by March 2002. Table 1 shows the list of respondents.

2/ Follows the IMF's de facto exchange rate regime classification as published in the IMF's International Financial Statistics.

3/ Corresponds to the Fund member developing and transition countries considered as emerging markets in the Fund's quarterly publication "Emerging Market Financing: A Quarterly Report on Developments and Prospects".

4/ The Central African Economic and Monetary Community (CAEMC) is itsclf a conventional fixed peg arrangement. 


\section{Table 26. Survey Respondents Announcing Ex Ante Foreign Exchange Intervention, by Exchange Rate Regime and Market Access, 2001 1/}

(In percent of countries answering the corresponding Survey question in each category)

\begin{tabular}{|c|c|c|c|}
\hline \multirow[t]{2}{*}{ Exchange rate regimes $2 /$} & \multicolumn{2}{|c|}{$\begin{array}{c}\text { Developing and Transition } \\
\text { Economies }\end{array}$} & \multirow[t]{2}{*}{ Total } \\
\hline & $\begin{array}{l}\text { Emerging } \\
\text { Markets 3/ }\end{array}$ & Other & \\
\hline No country-specific currency & -- & 50 & 50 \\
\hline CAEMC 4/ & - & 100 & 100 \\
\hline Other & -- & -- & -- \\
\hline Country-specific currency & 14 & 10 & 12 \\
\hline Currency board & -- & -- & -. \\
\hline Conventional fixed pegs against a single currency & 14 & 8 & 11 \\
\hline Conventional fixed pegs against a composite & -- & -- & -- \\
\hline Pegs with horizontal bands within a cooperative arrangement & -. & -- & -- \\
\hline Pegs with horizontal bands within a Fund supported program & -- & -. & -- \\
\hline Crawling pegs & -- & -- & -- \\
\hline Exchange rates within crawling bands & 20 & - & 14 \\
\hline Managed floating, no preannounced path for exchange rate & 20 & 10 & 16 \\
\hline Independently floating & 9 & 29 & 17 \\
\hline Total & 14 & 12 & 13 \\
\hline \multicolumn{4}{|l|}{ Memo item: } \\
\hline Number of countries answering question & 44 & 42 & 86 \\
\hline In percent of survey respondents & 100 & 91 & 96 \\
\hline
\end{tabular}

Note: -- stands for not applicable, zero, or negligible amount.

Source: IMF, 2001 Survey on Foreign Exchange Market Organization.

1/ The 2001 Survey on Foreign Exchange Market Organization was sent to country authorities in all Fund member developing and transition economies on October 2001. Ninety answers were received by March 2002. Table 1 shows the list of respondents.

2/ Follows the IMF's de facto exchange rate regime classification as published in the IMF's International Financial Statistics.

3/ Corresponds to the Fund member developing and transition countries considered as emerging markets in the Fund's quarterly publication "Emerging Market Financing: A Quarterly Report on Developments and Prospects".

4/ The Central African Economic and Monetary Community (CAEMC) is itself a conventional fixed peg arrangement. 


\section{Table 27. Survey Respondents Publishing Foreign Exchange Intervention Figures,} by Exchange Rate Regime and Market Access, 2001 1/

(In percent of countries answering the corresponding Survey question in each category)

\begin{tabular}{|c|c|c|c|}
\hline \multirow[t]{2}{*}{ Exchange rate regimes $2 /$} & \multicolumn{2}{|c|}{$\begin{array}{c}\text { Developing and Transition } \\
\text { Economies }\end{array}$} & \multirow{2}{*}{ Total } \\
\hline & Emerging Markets $3 /$ & Other & \\
\hline No country-specific currency & -- & -- & -- \\
\hline CAEMC 4/ & -- & -. & $\ldots$ \\
\hline Other & -- & -- & -- \\
\hline Country-specific currency & 27 & 12 & 20 \\
\hline Currency board & 50 & -- & 25 \\
\hline Conventional fixed pegs against a single currency & -- & -- & -- \\
\hline Conventional fixed pegs against a composite & 33 & -- & 14 \\
\hline Pegs with horizontal bands within a cooperative arrangement & -- & -- & -- \\
\hline Pegs with horizontal bands within a Fund supported program & -- & -- & -- \\
\hline Crawling pegs & -- & 50 & 33 \\
\hline Exchange rates within crawling bands & 20 & -- & 14 \\
\hline Managed floating, no preannounced path for exchange rate & 47 & 27 & 38 \\
\hline Independently floating & 18 & 13 & 16 \\
\hline Total & 27 & 11 & 19 \\
\hline \multicolumn{4}{|l|}{ Memo item: } \\
\hline Number of countries answering question & 44 & 45 & 89 \\
\hline In percent of survey respondents & 100 & 98 & 99 \\
\hline
\end{tabular}

Note: -- stands for not applicable, zero, or negligible amount.

Source: IMF, 2001 Survey on Foreign Exchange Market Organization.

1/ The 2001 Survey on Foreign Exchange Markct Organization was sent to country authorities in all Fund member developing and transition economies on October 2001. Ninety answers were received by March 2002. Table 1 shows the list of respondents.

2/ Follows the IMF's de facto exchange rate regime classification as published in the IMF's International Financial Statistics.

3/ Corresponds to the Fund member developing and transition countries considered as emerging markets in the Fund's quarterly publication "Emerging Market Financing: A Quarterly Report on Developments and Prospects".

4/ The Central African Economic and Monetary Community (CAEMC) is itself a conventional fixed peg arrangement. 
Table 28. Survey Respondents Requiring Foreign Exchange Licenses, by Exchange Rate Regime and Market Access, 2001 1/

(In percent of countries answering the corresponding Survey question in each category)

\begin{tabular}{|c|c|c|c|}
\hline \multirow[t]{2}{*}{ Exchange rate regimes $2 /$} & \multicolumn{2}{|c|}{$\begin{array}{c}\text { Developing and Transition } \\
\text { Economies }\end{array}$} & \multirow{2}{*}{ Total } \\
\hline & $\begin{array}{l}\text { Emerging } \\
\text { Markets 3/ }\end{array}$ & Other & \\
\hline No country-specific currency & -- & 100 & 100 \\
\hline CAEMC $4 /$ & -- & 100 & 100 \\
\hline Other & -- & 100 & 100 \\
\hline Country-specific currency & 82 & 91 & 86 \\
\hline Currency board & 100 & 100 & 100 \\
\hline Conventional fixed pegs against a single currency & 100 & 82 & 89 \\
\hline Conventional fixed pegs against a composite & 67 & 80 & 75 \\
\hline Pegs with horizontal bands within a cooperative arrangement & -- & -- & -- \\
\hline Pegs with horizontal bands within a Fund supported program & -- & 100 & 100 \\
\hline Crawling pegs & 100 & 100 & 100 \\
\hline Exchange rates within crawling bands & 80 & 100 & 86 \\
\hline Managed floating, no preannounced path for exchange rate & 87 & 91 & 88 \\
\hline Independently floating & 64 & 100 & 79 \\
\hline Total & 82 & 91 & 87 \\
\hline \multicolumn{4}{|l|}{ Memo item: } \\
\hline Number of countries answering question & 44 & 45 & 89 \\
\hline In percent of survey respondents & 100 & 98 & 99 \\
\hline
\end{tabular}

Note: -- stands for not applicable, zero, or negligible amount.

Source: IMF, 2001 Survey on Foreign Exchange Market Organization.

1/ The 2001 Survey on Foreign Exchange Market Organization was sent to country authorities in all Fund member developing and transition economies on October 2001. Ninety answers were received by March 2002. Table 1 shows the list of respondents.

2/ Follows the IMF's de facto exchange rate regime classification as published in the IMF's International Financial Statistics.

3/ Corresponds to the Fund member developing and transition countries considered as emerging markets in the Fund's quarterly publication "Emerging Market Financing: A Quarterly Report on Developments and Prospects".

4/ The Central African Economic and Monetary Community (CAEMC) is itself a conventional fixed peg arrangement. 